\title{
A DANÇA DOS NÚMEROS DA PREVIDÊNCIA SOCIAL REVISITANDO A AUDITORIA DO TCU DE $2017^{1}$
}

\author{
THE DANCE OF SOCIAL SECURITY NUMBERS \\ REVISITING THE 2014 COURT OF ACCOUNTS' AUDIT
}

Carlos Luiz Strapazzon ${ }^{2}$

Resumo: Este trabalho é uma versão revisada, atualizada e ampliada de outro trabalho já publicado na EJJL. Nesta versão, aprofunda-se o estudo do Relatório de Auditoria realizada pelo Tribunal de Contas da União (TCU) nas contas da Seguridade Social do Brasil (Acórdão no 1295/2017 (TC 001.040/2017-0). A Auditoria tomou em consideração as contas de 10 anos, alcançando o período que vai de 2007 a 2016. Todos os chamados "regimes previdenciários" administrados pela União Federal e que integram o conceito de Seguridade Social no Brasil foram auditados. Este estudo oferece uma análise descritiva e também crítica dos resultados apontados no documento do TCU. Os resultados do trabalho do TCU são extremamente importantes para as discussões da reforma da previdência social no Brasil. Qualificam o debate público sobre a existência, ou não, de desequilíbrios financeiros e sobre o tipo de déficits existentes. Mais que isso, revelam distorções, imprecisões, erros, negligências, desigualdades, inconsistências que, afinal, enriquecem o diagnóstico desse tema intrigante. Depois do Relatório do TCU a reforma da Previdência não pode ser reduzida a uma discussão simplista sobre política fiscal, déficit e longevidade dos brasileiros. Palavras-chave: Reforma da Previdência. Seguridade Social. Segurança Social. Seguro Social. Contas Públicas.

\begin{abstract}
This paper is a revised, updated and expanded version of another work already published in the EJJL. In this version, the study of the Audit Report carried out by the Brazilian Court of Accounts (TCU) in the Brazilian Social Security accounts (Judgment No. 1295/2017 (TC 001.040 / 2017-0)) is considered. The 10-year accounts, reaching the period from 2007 to 2016. All the socalled "social security regimes" administered by the Federal Government and that integrate the concept of Social Security in Brazil have been audited. The paper offers a descriptive and also critical assessment of the outcomes, which are extremely significant for the discussions on social security reform in Brazil, as well as they qualify the public discussion upon the existence or not of financial imbalances and upon the type of deficits that exist. Distortions, inaccuracies, errors, negligence, inequalities, inconsistencies are also highlighted, after all, enrich the diagnosis of this intriguing issue. Ever since the TCU Report 2017 was published such a debate can not be reduced to a simplistic discussion upon Brazil's fiscal policy, deficit and longevity.
\end{abstract}

Keywords: Social Security. Fiscal crisis. Social rights.

\footnotetext{
Versão inédita, atualizada e ampliada em 27 de maio de 2019.

2 Carlos Luiz Strapazzon, Doutor em Direito; Professor do Doutorado e Mestrado em Direito da Universidade do Oeste de Santa Catarina de Chapecó e da Universidade Positivo de Curitiba; Avenida Nereu Ramos, 3777-D, Seminário, 89813-000, Chapecó, Santa Catarina, Brasil; https://orcid.org/0000-0001-6595-548X; strapazzon.carlos.luiz@gmail.com
} 


\section{Introdução}

Este trabalho é um estudo de um Relatório de Auditoria realizada pelo Tribunal de Contas da União (TCU), órgão central do controle de contas públicas do Brasil.

Em 26 de junho de 2017 o Tribunal de Contas da União publicou o Acórdão no 1295/2017 (TC 001.040/2017-0) e, por meio dele, o Relatório da Auditoria nas contas da Seguridade Social do Brasil. ${ }^{3} \mathrm{O}$ objetivo do levantamento foi apurar informações sobre as contas, a forma de gestão e, particularmente, sobre a existência (ou não) de déficit da Previdência administrada pela União Federal. ${ }^{4}$ A Auditoria tomou em consideração as contas de 10 anos, alcançando o período que vai de 2007 a 2016. Todos os chamados "regimes previdenciários" administrados pela União Federal e que integram o conceito de Seguridade Social no Brasil foram auditados. Ou seja, foram avaliados os dados da Saúde, da Assistência Social, dos benefícios do Regime Geral da Previdência Social (RGPS), ${ }^{5}$ dos benefícios do Regime Próprio de Previdência Social dos Servidores Públicos da União (RPPS-União) ${ }^{6}$ e dos benefícios dos Encargos Previdenciários da União (EPU) ${ }^{7}$ com militares e seus pensionistas, como também todos os demais tipos de pensões especiais pagas pela União nessa modalidade de benefícios. Assim, a Auditoria concentrou-se na análise das receitas e despesas de todo o arranjo que compõem o conceito abrangente de Seguridade Social ${ }^{8}$ no Brasil.

Os resultados do trabalho do TCU são extremamente importantes, quer para a pesquisa acadêmica, quer para a tomada de decisões políticas. Qualificam o debate público sobre a existência, ou não, de desequilíbrios financeiros e sobre o tipo de déficits existentes. Mais que isso, revelam distorções, imprecisões, erros, negligências, desigualdades, inconsistências e uma série de problemas que enriquecem o diagnóstico para que a reforma da Previdência não se reduza a uma discussão simplista sobre déficit, aposentadoria por tempo de contribuição e longevidade.

3 O trabalho do TCU contou com a participação de quatro unidades técnicas do Tribunal: SECEX-PREVIDÊNCIA | Secretaria de Controle Externo da Previdência; SEMAG | Secretaria de Macroavaliação Governamental; SECEX FAZENDA | Secretaria de Controle Externo da Fazenda Nacional e SEFIP | Secretaria de Fiscalização de Pessoal.

4 Em Auditoria sobre a Previdência dos Estados e Municípios, com ajuda de 26 Tribunais de Contas Estaduais, foi calculado um déficit financeiro da ordem de R \$ 32,5 bilhões para o ano de 2014 relativo a 2.129 planos administrados pelos RPPS estaduais e municipais (TCU. Acórdão 1331/2016-TCUPlenário).

5 Lei 8.212/1991 - Dispõe sobre Plano de Custeio da Seguridade Social, Lei 8.213/1991 - Dispõe sobre os Planos de benefícios de Previdência Social. O caso da cobertura do desemprego involuntário é uma exceção, visto que é viabilizado pelo mecanismo do Fundo de Garantia por Tempo de Serviço e não gera nem despesas, nem receitas para o RGPS (Lei 8.213/1991, art. $\left.9^{\circ}, \$ 1^{\circ}\right)$. É uma situação de conflito com o texto constitucional, que determina que a Previdência deveria geri-lo como modalidade de benefício previdenciário.

6 Lei 8.112/1990, estabelece regras específicas do RPPS da União, Lei 9.717/1998, dispõe sobre regras gerais para a organização e o funcionamento dos regimes próprios de Previdência Social dos servidores públicos da União, dos Estados, do Distrito Federal e dos Municípios, dos militares dos Estados e do Distrito Federal, a Lei 12.618/2012 instituiu o regime de Previdência complementar para os servidores públicos federais titulares de cargo efetivo, a Lei 10.887/2004 disciplina o cálculo dos proventos de aposentadorias e pensões dos RPPS, a Lei 9.506/1997 extinguiu o Instituto de Previdência dos Congressistas (IPC) e instituiu o Plano de Seguridade Social dos Congressistas (PSSC).

7 A Lei 6.880/1980 dispõe sobre o Estatuto dos Militares, a Lei 3.765/1960 dispõe sobre as pensões militares. No caso dos militares não há previsão legal para que eles contribuam para custear os encargos da inatividade, apenas para pensão (Lei 3.765/1960). Assim, cabe à União custear a integralidade da remuneração daqueles militares que estão na inatividade. Os militares têm direito de receber da União tantas quotas de soldo quantos forem os anos de serviço, computáveis para a inatividade, até o máximo de trinta anos.

8 TCU (2017a, p. 10). 


\section{Regimes previdenciários próprios e impróprios}

Muito embora a doutrina usualmente classifique os regimes previdenciários em 3 tipos (Regime Geral de Previdência Social-RGPS, Regime Próprio de Previdência dos Servidores Públicos RPPS e Regime Complementar privado), ${ }^{9}$ a Auditoria do TCU não afirma, mas por meio dela se pode ver a existência de mais regimes. Isso quer dizer que ao ler o Relatório nota-se que o TCU lida com uma tal diversidade de regimes que apontam para a existência de mais do que 3 regimes. A despeito disso, o TCU preferiu classificar os fundos previdenciários e os modelos de Previdência sem questionar a tradicional classificação adotada pela legislação e pela doutrina. A escolha é bem compreensível, já que um Relatório de Auditoria não é lugar para a crítica conceitual. Isso não significa, porém, que as diferenças entre direitos e deveres de grupos de segurados sociais fique limitada a essas modalidades conhecidas e que o próprio Relatório chama de "regimes".

Nas regras de Previdência para servidores públicos verificam-se - só na esfera da União Federal - 7 modelos especializados de contribuições e de benefícios previdenciários. Cada um tem suas regras e segurados diferenciados, junto com direitos e deveres também diferenciados. Ocorre que uma modalidade particular de regulação jurídica para um grupo de pessoas que comungam de semelhante situação fática configura um tipo especial de regime jurídico. Dizer que a União Federal tem apenas "um Regime Próprio", depois de identificar 7 modelos diferentes de regulação, no fundo obscurece um fato importante: a existência de muitos regimes previdenciários diferentes para servidores públicos federais.

$\mathrm{Na}$ análise deste Relatório de Auditoria do TCU adotaremos a seguinte classificação. O Brasil tem 4 grupos de clientelas para a Previdência: a clientela que trabalha no setor privado, ou que trabalha no setor público mas não na condição de servidor(a) de regime estatutário. Essa clientela é regida pelo sistema público do RGPS, com fundo próprio, o FRGPS e é administrado pelo INSS. Também há a clientela de servidores públicos que não é contratada pelo regime da CLT (são os servidores estatutários) e que tem um regime de previdência diferente do RGPS. Essa clientela tem diferentes regimes próprios previdenciários, depende muito do Poder, da unidade federada e da área em que atuam. Entretanto, todos têm em comum o fato de ter uma Previdência pública que não é administrada pelo INSS. O arquipélago de regimes previdenciários de servidores públicos da União

\footnotetext{
9 Um bom indicativo da força dessa classificação trinária é seu uso corrente em documentos oficiais, como é o caso do Relatório de Prestação de Contas da Presidência da República, 2016, publicado em abril/2017. Na definição da Seguridade Social e Previdência Social encontra-se o seguinte: A Previdência Social está organizada em três regimes distintos, independentes entre si: Regime geral de caráter contributivo e de filiação obrigatória ...; Regime próprio dos servidores públicos titulares de cargos efetivos da União, dos Estados, do Distrito Federal e dos Municípios, incluidas suas autarquias e fundações; é um regime de previdência de caráter contributivo e solidário, mediante contribuição do ente público, dos servidores ativos, aposentados e pensionistas, observados critérios que preservem o equilíbrio financeiro e atuarial. (Art. 40, CF/88); e o Regime de previdência complementar organizado de forma autônoma em relação aos regimes públicos, facultativo, baseado na constituição de reservas que garantam o benefício contratado, e regulado por lei complementar (Art. 202, CF/88). (p. 243).
} 
Federal, dos Estados e dos Municípios é usualmente unificado num só conceito — apesar de ser um erro classificá-lo assim — o de RPPS-União Federal ou RPPS-Estados, ou RPPS-Municípios.

Há também a clientela dos pensionistas dos EPU, com aposentadorias e pensões especiais administradas pelo INSS mas que não fazem parte do sistema de seguro sociais contributivo, que é o que caracteriza a Previdência Social.

Por fim, há o caso dos segurados que têm contratos privados (e voluntários) de Previdência complementar, administrados por fundos privados de Previdência, portanto também fora do INSS. Não vamos tratar deste último caso, nem da Previdência de Estados e Municípios. Como a União Federal é que foi objeto da Auditoria do TCU, este trabalho se concentra apenas no caso dos regimes de previdência administrados pela União Federal.

A Auditoria revela que a União Federal administra 7 regimes especiais de Previdência. ${ }^{10}$ Uma análise pormenorizada desse quadro revela o seguinte: um regime é o do INSS. Ali está a clientela dos segurados contribuintes que atuam no setor privado ou no setor público (desde que o servidor não tenha sido contratado em regime estatutário ou, se foi, se é servidor de um Estado ou Município que não adota regime especial de Previdência para servidor público). Esse regime é usualmente chamado de Regime Geral da Previdência Social (RGPS) e é administrado pelo INSS. Outro regime é o dos benefícios pagos a servidores públicos civis da União, também contribuintes, que desde 1998 é denominado de Regime Próprio de Previdência Social (RPPS) e que tem 4 subdivisões (RPPS); ${ }^{11}$ depois há o regime dos benefícios devidos aos servidores militares das forças armadas, diferente daqueles, estes não são contribuintes, e é denominado de Regime de Encargos Previdenciários da União com Militares e seus pensionistas (EPU). Além desses casos, o Relatório revela que a União Federal paga benefícios previdenciários e/ou pensões especiais, na modalidade de Encargos Previdenciários da União, a outros 12 grupos diferentes de beneficiados. ${ }^{12}$

10 Idem, p. 6-9.

11 O RPPS merece um esclarecimento adicional. Tomando-o apenas pelo nome "regime próprio de Previdência de servidores", fica a impressão de que todos os servidores públicos civis da União têm, rigorosamente, as mesmas regras previdenciárias, isto é, os mesmos direitos e deveres materiais e processuais. Mas não é assim. Dentro dessa esfera da Previdência existem 4 sub-regimes relativamente diferentes entre si: o regime de Previdência dos servidores de carreira do Ministério Público Federal, o dos servidores de carreira do Poder Judiciário, o dos membros do Poder Legislativo e o dos servidores do Poder Executivo além, é claro, o dos Militares. Sobre essa fragmentação de gestão de regimes previdenciários dentro da estrutura da União Federal, vale lembrar que é inconstitucional. Desde 2003 existe uma regra especial no Art. 40 que trata exatamente disso. É a seguinte: Art. 40 \$20. Fica vedada a existência de mais de um regime próprio de Previdência Social para os servidores titulares de cargos efetivos, e de mais de uma unidade gestora do respectivo regime em cada ente estatal, ressalvado o disposto no art. 142, $\mathbb{S} 3^{\circ}$, X, ou seja, o caso dos Militares. Sobre isso o TCU considerou o seguinte: ... Ressalva-se que independentemente da situação atuarial do RPPS, a criação da Unidade Gestora Única é importante para um melhor acompanhamento e controle dos gastos com a previdência, sendo indicada mesmo que não se constate déficit [pois diante da complexidade dos dados, TCU não chegou a uma conclusão a esse respeito]. Como apresentado, o déficit apontado na avaliação atuarial que do PLDO 2018 não permite concluir sobre sustentabilidade financeira ou equilíbrio previdenciário, devendo ser entendido como o montante de recursos necessários para fazer frente às obrigações futuras da União, desde que novos servidores não sejam admitidos no atual RPPS e os servidores e beneficiários atuais sejam mantidos com as mesmas regras até o falecimento (TCU, 2017a, p. 122).

12 Os demais Encargos Previdenciários da União (EPU) são os seguintes: (5.1.) com inativos e pensionistas da Polícia Civil, da Polícia Militar e do Corpo de Bombeiros Militar do Distrito Federal (inc. XIV do art. 21 da CF/88) e dos extintos estados e territórios, (5.2) pensionistas do caso do Estado do Mato Grosso, decorrente da subdivisão territorial prevista pelo Art. 27 da Lei Complementar 31/1977, (5.3) pensionistas da extinta via férrea do Rio Grande do Sul (Lei 3.887/1969) e (5.4) a pensão especial aos ferroviários da antiga RFFSA (Lei n. 593/48 e Lei n 1.434/1951), (5.5) a pensão mensal com caráter 
A elevada fragmentação do sistema brasileiro de Previdência é notável. Respostas simplistas para problemas nessa área, portanto, devem ser evitadas, pois é alta a chance de abordarem muito parcial do tema. Quando se diz que "a Previdência tem déficit", é preciso saber, exatamente, do que se fala, de que regime, e quais benefícios são responsáveis pelo déficit. A variação de resposta pode ser muito significativa, dentro do quadro (desnecessariamente) complexo desse sistema de segurança social de renda.

Por outro lado, esse panorama explicita a flagrante desigualdade do modelo brasileiro de seguro social. A desigualdade perpassa os múltiplos regimes destinados a servidores públicos, com destaque para o especialíssimo modelo dos servidores militares e servidores civis da União. Por outro lado, é verdade também que esses regimes guardam entre si um certo grau de complementaridade, ${ }^{13}$ pois admitem a contagem recíproca de tempo de contribuição na administração pública e na atividade privada, seja ela rural ou urbana, e também compensação financeira entre os regimes, inclusive quando prestado às Forças Armadas. ${ }^{14} \mathrm{E}$ mais, caso alguma das unidades federadas (Município, Estados ou União) deixar de estabelecer um regime especial de Previdência Social, seus servidores serão obrigatoriamente ${ }^{15}$ filiados ao RGPS.

Se bem analisados os resultados da Auditoria do TCU, não será difícil concluir que a denominação de "Regime Próprio" para a Previdência dos Servidores Públicos é, na realidade uma denominação inadequada. Essa classificação tem amplo amparo doutrinário e também legal, porém não está imune a críticas.

Inicialmente, esse é um dos raros casos (talvez o único) em que a linguagem jurídica aplica o adjetivo próprio para indicar oposição a algo que é geral. ${ }^{16}$ Evidentemente que o par dialético do

\footnotetext{
de indenização devida a anistiados políticos - pensão em vida e pensão por morte paga a dependentes (Leis $10.559 / 2002$ e 11.354/2006); (5.6) a pensão por morte estatutária, paga a dependentes de servidor público (Lei 8.112/90, Art. 215 e ss.); (5.7) aposentadoria de pessoal extranumerário da Imprensa Nacional da extinta CAPIN - Caixa de Aposentadoria e Pensões da Imprensa Nacional (Decreto-Lei n 6.209/1944); (5.8) pensão mensal vitalícia com caráter de indenização, paga a portadores da Síndrome da Talidomida nascidos a partir de $1^{\circ}$ de março de 1958 , data do início da comercialização mundial da droga (Lei 7.070/1982, Art. 4.), porque o Brasil atrasou 4 anos a proibição da comercialização da droga, depois de ter sido suspensa a venda nos EUA e na Europa em 1961, e depois ainda falhou gravemente no controle da circulação clandestina; (5.9) pensão mensal vitalícia com caráter de indenização a vítima da hanseníase que tenha sido submetida a isolamento e internação compulsória em hospitais-colônias até 31.12.1986; (5.10) pensão mensal vitalícia de 2 SM a seringueiros "soldados da borracha", recrutados nos termos do Decreto-Lei n 5.813/1943 para trabalhar na Amazônia durante a II Guerra mundial; (5.11) pensão mensal vitalícia a dependente do seringueiro; (5.12) pensão especial de 1 SM a dependente de vítima fatal da hepatite tóxica, por contaminação em processo de hemodiálise no Instituto de Doenças Renais de Caruaru-PE, entre fevereiro e março de 1986 (Lei 9.422, 24.12.1996).

13 Ver CRFB, Art. 201, \ $9^{\circ}$.

14 Ver Lei 8.112/90, Art. 100

15 Ver Lei 8.213/90, Art. 12.

16 Na linguagem técnica do direito, como na linguagem comum em geral, o oposto de "geral", costuma ser "especial". Assim é, por exemplo, quando se enuncia o famoso brocardo aplicável à solução de antinomias: norma "especial" prevalece diante de norma "geral", ou mesmo quando se diz que a Justiça brasileira se estrutura a partir do ramo "especializado" em temas eleitorais, trabalhistas e militares. Mais ainda, os códigos brasileiros, como é o caso do código de direito penal subdivide-se em "parte geral" e "parte especial". O mesmo vale para o Código Civil (2002) ou para o Código de Processo Civil (2015). Não é preciso ir mais longe na lista de exemplos. Na linguagem técnica do direito, o termo apropriado para dizer o oposto de "geral ou comum" é "especial". Se na arena previdenciária o termo mais usual é "próprio", isso merece reparo e crítica, pois a linguagem obscurece o fenômeno. Uma coisa é dizer que servidores públicos tem seu "próprio" regime previdenciário. Outra bem diferente é afirmar que o tratamento dado a servidores públicos é "especial", portanto, diferente daquele conferido ao "geral" dos brasileiros. Na arena democrática, o que é "próprio" não precisa de densa justificação. Mas o que é "especial", sim. E toda diferenciação entre sujeitos essencialmente semelhantes, precisa de densa justificação baseada em razões coerentes com os princípios democráticos e republicanos.
} 
vocábulo geral é o vocábulo especial. E não, como fez a EC n. 20/1998, o vocábulo próprio (que tem seu par dialético no termo impróprio). Classificar os regimes previdenciários como "Regime Geral" (para todos) e "Regime Próprio" (para servidores públicos), revela uma notável superficialidade que protege um preconceito político. É um desvio dos objetivos da filosofia constitucional da segurança social do Brasil que, introduzida a partir da Assembleia Nacional Constituinte, determinou a edificação de um sistema integrado de ações no campo da Previdência, saúde e assistência social "para todos" e controlado pela "comunidade". ${ }^{17}$

A bem da verdade, num regime republicano ninguém poderia ter direito a regime jurídico "próprio"18 para qualquer tema. Isso indica preconceito aristocrático superado em 1889 e apego à antiga doutrina dos direitos naturais de classes. Em democracias republicanas os cidadãos se sujeitam a duas modalidades de regras: as regras "gerais" e a regras "especiais". Essas últimas, aliás, são abundantes em qualquer democracia porque extremamente necessárias. É por meio de regras especiais que se pode assegurar a realização da justiça nos casos concretos, o tratamento individualizado, excepcional e especial na medida em que se pode distinguir o todo e a parte. Todavia, denominar o modelo previdenciário entre brasileiros em regime geral e regime próprio de servidores públicos é obscurecer o fato mais evidente: que no Brasil os servidores públicos têm muitas regras especiais protegendo de modo diferente e injustificável muitas e diferentes categorias de servidores. Isso é mais um sinal de porque a Previdência Social no Brasil ainda não está devidamente integrada. ${ }^{19}$

Essa crítica é relevante pois se nas democracias as regras especiais podem coexistir com o princípio da igualdade, o tratamento especial sempre reclama justificação adicional. Em princípio, todos devem ter o mesmo tratamento, todos são iguais perante a lei. Excepcionalmente, no entanto,

\footnotetext{
$\overline{17}$ A propósito disso, é importante lembrar que a redação original do texto constitucional, para o Art. 194, \único, inciso VII, era a seguinte: "caráter democrático e descentralizado da gestão administrativa, com a participação da comunidade, em especial de trabalhadores, empresários e aposentados". Essa norma tem natureza de princípio constitucional. Princípio de organização institucional do Estado. A despeito de jamais poder ser revogada, justamente por ser princípio de organização do Estado, foi revogada e sem maiores discussões públicas, substituída pela seguinte: VII - caráter democrático e descentralizado da administração, mediante gestão quadripartite, com participação dos trabalhadores, dos empregadores, dos aposentados e do Governo nos órgãos colegiados, na redação dada pela Emenda Constitucional n ${ }^{\circ} 20$, de 1998. Vendo a versão que ficou, é fácil notar o desvio (inconstitucional) proposto pela reforma de 1998. O que antes era uma diretriz de controle republicano dos objetivos da segurança social (pela comunidade), passou a ser uma diretriz de controle por órgão de Estado (órgãos colegiados). O Estado capturou a sociedade e, obviamente, atrofiou a filosofia da segurança social que deveria receber um modelo de controle comunitário, pois esse foi o objetivo estabelecido pela Assembleia Nacional Constituinte.

18 O termo "regime próprio" de Previdência foi criado pela EC 20/1998. Constava do caput do Art. 40 da redação original proposta pela Mensagem Presidencial n. 306/95, que previa o seguinte: Ao servidor da União, dos Estados e do Distrito Federal e dos Municípios, incluídas suas autarquias, é assegurado regime próprio de Previdência, na forma de lei complementar prevista no Art. 201 [...] Essa redação foi modificada e a expressão "regime próprio" não apareceu mais na versão final do caput do Art. 40. Em seu lugar constou, na versão final, que aos servidores titulares de cargos efetivos seria assegurado regime de Previdência de caráter contributivo. E depois, com a EC 41/2003, ficou assim: [...] Aos servidores titulares de cargos efetivos [...] é assegurado regime de Previdência de caráter contributivo e solidário.

19 No sítio da Câmara dos Deputados é possível encontrar informações sobre a PEC 172/1993, proposta pelo então Deputado Eduardo Jorge, que tinha o propósito de eliminar esses múltiplos regimes e instituir o regime básico unificado de Previdência Social. Eduardo Jorge foi um dos deputados mais influentes na Comissão de Direitos Sociais da Assembleia Nacional Constituinte e um dos responsáveis pela criação do conceito de "Seguridade Social" no texto constitucional. Segundo o autor da PEC 172, eliminar o arquipélago de regimes era um passo fundamental para que o Brasil pudesse, de fato, avançar na efetivação da Seguridade Social como regime integrado de ações.
} 
é legítimo instituir regras especiais para pessoas e situações que, por razões consistentes com os ideais de justiça, democracia e república sejam, efetivamente, merecedoras de tratamento diferenciado.

Pensando assim, o que justifica denominar o "regime de Previdência" dos servidores públicos como um "regime próprio"? (ou seja, como RPPS). Da perspectiva democrática e republicana, à primeira vista, nada. É certo que existem causas históricas que espelham os conflitos e os preconceitos de classe para esse desenho vigente — com tantos grupos diferenciados de benefícios e de contribuições.

Embora haja também alguns casos, como ocorre com parte dos EPU, para os quais é a justa indenização que explica o atual tratamento particular, essa não parece ser a principal razão de o Brasil adotar tantas diferenciações na gestão da Previdência para servidores públicos. Por detrás do escudo conceitual do regime próprio de Previdência de servidores públicos, há muitas décadas de convivência com a desigualdade de tratamento para funcionários públicos e para trabalhadores em geral. A bem da verdade, seria preciso uma pesquisa histórica e sociológica mais avançada para verificar a seguinte hipótese adotada neste trabalho: a política de Previdência, no Brasil, particularmente a da Previdência de servidores públicos, de um lado expressa as lutas políticas pela ocupação de espaços e pela captura de recursos estatais. De outro, é um dos mais importantes recursos políticos mobilizados por governos para viabilizar estratégias de dominação. Com o passar dos últimos 30 anos, a sociedade brasileira aceitou a cristalização dessas assimetrias. E o tema se tornou invisível (ou demasiado complexo e, assim, obscuro) para vir ao debate público. As novas gerações de cidadãos do regime geral aceitam o que temos hoje com perplexidade.

Mas esse não é o tema principal deste trabalho. Essa digressão serve apenas para explicar que evitarei o termo regime próprio de Previdência de servidores públicos neste texto. Considero-o antirrepublicano e incompatível com a inovadora filosofia da segurança social estabelecida pela Assembleia Nacional Constituinte, no Capítulo VIII do texto constitucional. Em seu lugar adotarei regimes especiais de Previdência de servidores públicos sempre que o texto fizer referência à sigla RPPS.

\section{0 sistema solidário e a filosofia da segurança social ${ }^{20}$}

O Brasil é uma democracia com um impressionante sistema de direitos constitucionais sociais. É um país que constitucionalizou o que há de mais avançado no sistema internacional de direitos humanos. Desde o reconhecimento do amplo alcance dos direitos sociais como direitos fundamentais individuais, até o impressionante (e único) desenho constitucional de segurança social, perfeitamente alinhado com as diretrizes mínimas da Convenção 102/1952, da Organização

\footnotetext{
20 O TCU examinou dados do Sistema Integrado de Administração Financeira do Governo Federal (Siafi) Gerencial (2007) e Tesouro Gerencial (2008-2016), confrontou esses dados com as informações da Secretaria do Tesouro Nacional (STN) e da Secretaria de Orçamento Federal (SOF), abrangendo o período de 2007 a 2016. Examinou também os demonstrativos financeiros da União, em especial o Relatório Resumido da Execução Orçamentária (RREO) e, no caso do RGPS, o fluxo de caixa do INSS.
} 
Internacional do Trabalho e também com os objetivos do desenvolvimento sustentável (2015). A despeito de tanto progresso na capacidade de escrever direitos sociais, e de começar a obra, o Brasil ainda é um país que precisa de acordos básicos estáveis sobre a função econômica e política da segurança social coletiva (STRAPAZZON; TRAMONTINA, 2016). A segurança social coletiva não deveria ser confundida com "segurança pública", nem com "segurança jurídica", menos ainda com "segurança paga pelo Estado". A segurança social é um modo de proteção coletiva com intenso envolvimento das pessoas, comunidades, empresas, governos. É uma teia com muitos pontos interligados. Como o Brasil nunca teve isso, a experiencia dos últimos 30 anos com o SUS, o RGPS e o SUAS ainda geram desconfianças, dissabores e dúvidas. É que muitos objetivos da Assembleia Nacional Constituinte, neste ponto, ficaram pelo meio do caminho. $\bigcirc$ Brasil ainda não conseguiu realizar as potencialidades dessas 3 instituições.

Parte do sistema público de Previdência se organiza a partir de regras financeiras de repartição simples e de benefício definido. Isso vale para o RGPS e para o RPPS. Quer dizer que as pessoas jurídicas e parte dos segurados pessoas físicas (os que estão em atividade profissional) contribuem para financiar o pagamento dos benefícios definidos em lei em favor dos segurados que já adquiriram o direito de recebê-los ${ }^{21}$ (sejam pensões, auxílios ou aposentadorias). Além disso, quer dizer também que os benefícios futuros são calculados a partir de regras pré-estabelecidas. É bom notar que nesse modelo brasileiro o Estado tem um papel gerencial e suplementar decisivo. Nesse modelo "os riscos biométricos (associados à longevidade, morte, invalidez, entre outros) e financeiros são assumidos pelo patrocinador que, no caso [...] é a União."22 Portanto, é uma característica relevante do sistema brasileiro de financiamento da Previdência pública que a União tem o dever ${ }^{23}$ jurídico de cobrir desequilíbrios financeiros, seja do RGPS, seja do RPPS-União, seja dos EPU.

Se à primeira vista esse modelo parece economicamente irracional, a bem da verdade, não é. Esse modelo foi estruturado para realizar-se com equilíbrio financeiro e atuarial, na maior medida possível. Ou seja, é algo que funciona se a coordenação e gestão foram dinâmicas, compreenderem mudanças e se as despesas de curto, médio e longo prazos puderem ser cobertas com as receitas previstas (e se continuarem a existir). Além de ser pensado para funcionar com equilíbrio e com flexibilidade diante das mudanças sociais e econômicas, sua característica principal é a proteção universal - para todos - com financiamento universal e solidário - por todos. Por isso, a Assembleia Nacional Constituinte determinou a criação de um Orçamento da Seguridade Social à parte do Orçamento Fiscal. É como se fossem duas contas ou fundos separados. Cada um deve realizar objetivos diferentes. Como a prioridade é a qualidade de vida das pessoas com responsabilidade

\footnotetext{
21 É bom não generalizar neste ponto. Nem todos os segurados que recebem benefícios previdenciários, tais como pensões, aposentadorias, auxílios, nem todos são segurados inativos. Em muitos casos é possível ser, por exemplo, um segurado em atividade econômica que recebe um benefício previdenciário, como o de aposentadoria, já que para receber aposentadoria por idade ou proporcional ao tempo de serviço não precisa ser, necessariamente, um segurado inativo.

$22 \operatorname{TCU}(2017 \mathrm{a}$, p. 5, \$ 26).

23 Lei 8.212/91, Art. 16; Lei 9.717/1998, Art. 2., Lei 10.887/04, Art. $8^{\circ}$ \único.
} 
coletiva, então a segurança de renda e de saúde para todos foi vinculada ao Orçamento da Seguridade Social. Esse orçamento é financiado com um tipo de tributo pago por todos os brasileiros: as

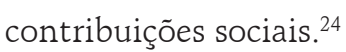

Todavia, na medida em que eventuais desequilíbrios entre receitas e despesas não são superados por receitas espontâneas de contribuições sociais, toda sociedade deve financiar eventuais déficits. Isso deve ser feito pelo governo, por meio de desvio de receitas de impostos para o orçamento da Seguridade Social. É bom salientar que não é "o governo" quem paga essa diferença. São os recursos de impostos que devem ser usados para proteger a política de segurança social. Afinal, se toda sociedade se beneficia das políticas de saúde, assistência social e Previdência (RGPS, RPPS e EPU), é razoável que todos, pessoas físicas e jurídicas, devem participar do financiamento.

A questão mais importante, portanto, não é o fato de a União ter de cobrir eventuais desequilíbrios com recursos de impostos (ou do orçamento fiscal). $\bigcirc$ mais importante é saber se o atual modelo é justo e eficiente. E se não for, é preciso saber se o problema é de concepção do modelo ou de gestão.

\section{Pagar e repagar: contribuições, impostos e desperdícios}

O Art. 195 da CRFB estabelece que os serviços e benefícios pagos pela Seguridade Social serão financiados por toda a sociedade, com recursos do orçamento de Municípios, Estados, Distrito Federal e União, além de recursos especiais decorrentes de Contribuições Sociais. ${ }^{25}$ Assim, majoritariamente, dois tributos financiam a Seguridade Social: as Contribuições Sociais, prioritariamente, e os impostos, como complemento. ${ }^{26}$

Os Impostos são arrecadados pelos entes federados e são aplicados em Seguridade Social em dois momentos: o primeiro é para garantir a quota patronal da Previdência de servidores públicos (CRFB, Art. 40). É que os municípios, Estados, DF e União Federal, quando adotam o RPPS, depositam mensalmente nos fundos previdenciários de servidores públicos uma quantia nunca inferior ao que

\footnotetext{
$\overline{24}$ Há alguns tipos de Contribuições Sociais mais populares. Uma delas é o desconto em folha de salários. Não custa lembrar que se ao final do mês um empregado notar que em sua folha de pagamentos consta um desconto com a informação "Desconto INSS" ou só "INSS", isso é só um registro contábil muito simplificado do que é a realidade. Quer dizer que o trabalhador está pagando, com desconto direto na folha de salários, a sua contribuição social para o funcionamento do sistema de Previdência. Nesse caso específico, está pagando a Contribuição Previdenciária. Outras Contribuições Sociais são bem conhecidas, mas pagas por empregadores (lato sensu). Assim a Contribuição Patronal para a Previdência Social, a COFINS, o PIS/PASEP e a CSLL.

25 Ver Lei 8.212/91, Art. 11. No âmbito federal, o orçamento da Seguridade Social é composto das seguintes receitas: I - receitas da União; II - receitas das contribuições sociais; III - receitas de outras fontes. Parágrafo único. Constituem contribuições sociais: a) as das empresas, incidentes sobre a remuneração paga ou creditada aos segurados a seu serviço; b) as dos empregadores domésticos; c) as dos trabalhadores, incidentes sobre o seu salário-de-contribuição; d) as das empresas, incidentes sobre faturamento e lucro; e) as incidentes sobre a receita de concursos de prognósticos.

26 Lei 8.212, Art. 16. A contribuição da União é constituída de recursos adicionais do Orçamento Fiscal, fixados obrigatoriamente na lei orçamentária anual. Parágrafo único. A União é responsável pela cobertura de eventuais insuficiências financeiras da Seguridade Social, quando decorrentes do pagamento de benefícios de prestação continuada da Previdência Social, na forma da Lei Orçamentária Anual.
} 
cada servidor contribui para o mesmo fundo. No caso da União Federal, o depósito é o dobro do valor que é pago pelos servidores. ${ }^{27}$

É um modelo que, de certo modo, acompanha o que ocorre no setor privado: como os empregadores e empregados privados pagam contribuições para o financiamento da Seguridade Social de empregados (não diretamente dos seus, mas de todos os empregados do mercado brasileiro), os municípios e Estados transferem aos fundos previdenciários de seus servidores uma quantia equivalente ao que os próprios servidores recolhem mensalmente.

A diferença importante é que o Estado brasileiro não paga tributos como um empregador do setor privado. $\bigcirc$ Estado apenas aloca, para servidores públicos, receitas tributárias recolhidas de toda a sociedade. Esta é quem paga impostos e contribuições sociais. Então, esses recursos adicionais da chamada "quota patronal" que beneficiam os servidores públicos, derivam da receita de impostos recolhidos de toda a sociedade.

Esse panorama indica o seguinte: a sociedade brasileira paga quatro vezes para a Previdência. Primeiro quando recolhe contribuições previdenciárias para prover os recursos necessários para o RGPS, fundo esse que protege a clientela denominada como "segurados em geral". Se não houvesse outra clientela de Previdência, ou seja, se a Previdência de todos os servidores públicos também fosse administrada pelo INSS, os pagamentos encerrariam aqui. $O$ segundo pagamento ocorre indiretamente e, por isso, não é percebido. Mas existe de fato. Efetiva-se quando a União, Estados ou Municípios alocam receitas de impostos para pagar a "quota patronal" da Previdência de servidores públicos, no denominado "regime RPPS". A quota patronal é uma fantasia jurídica, pois o Estado arrecada tributos de toda a sociedade. Não paga tributos. Logo, receitas de impostos é que pagam a "quota patronal" da previdência de servidores públicos. $\bigcirc$ terceiro e quartos momentos ocorrem se houver desequilíbrio financeiro nesses dois arranjos. Havendo desequilíbrio entre receitas e despesas no RPPS, será preciso prover mais recursos. Igualmente, se houver desequilibro financeiro na Previdência dos brasileiros "em geral", vinculados ao RGPS, a União utilizará do endividamento ou de receitas de impostos para socorrer o desequilíbrio. Evidentemente que se a Previdência de servidores públicos e a Previdência do RGPS estiverem em déficit, então aumentará a necessidade de endividamento ou de desvio de receitas de impostos - que só excepcionalmente deveriam migrar para a área da Seguridade Social — para proteger as necessidades da saúde, assistência social e Previdência.

As contribuições previdenciárias (um tipo específico de Contribuição Social) são as receitas básicas que financiam os fundos públicos de Previdência. Elas são pagas por (a) empregadores com valor calculado mês a mês a partir do montante da folha de salários de cada pessoa jurídica. Além dessas, a seguridade social tem outras receitas próprias, isto é, receitas de contribuições sociais diferentes das primeiras e que podem ser calculadas também a partir de outras bases, todas previstas na CRFB, tais como a receita bruta (COFINS, PIS/PASEP) ou, ainda, o lucro de pessoas jurídicas

\footnotetext{
${ }^{27}$ Art. $8^{\circ}$. da Lei 10.887/2004.
} 
determinadas (CSLL). Cada caso tem leis próprias e regulação específica. A variação depende do setor e não significa que todas as pessoas jurídicas pagam, cumulativamente, contribuições sociais a partir de todas essas bases. Além das pessoas jurídicas, (b) os empregados e servidores públicos também pagam contribuições para a Previdência (num caso, destinado ao RGPS, noutro ao RPPS), calculada sobre a folha de salário individual e com valores diferentes, de acordo com a faixa salarial individual. Além dessas, existe a cobrança de (c) contribuição social sobre a receita de concursos de prognósticos, isto é, de serviços lotéricos, e (d) por fim, do importador de bens ou serviços do exterior.

Como se vê, o Brasil tem um modelo muito particular de financiamento das despesas da Seguridade Social e das demais políticas públicas. Por um lado, a receita das Contribuições previdenciárias deve sustentar o fundo previdenciário (do RGPS ou do RPPS), e a das contribuições sociais devem sustentar as necessidades da política de saúde e de assistência social; por outro, a receita de contribuições previdenciárias arrecadadas a partir da folha de pagamentos de servidores públicos (acrescida de uma parte das receitas de impostos arrecadados de toda a sociedade - a quota patronal paga pelo Estado) devem sustentar os múltiplos fundos previdenciários de servidores públicos. Por fim, a receita de impostos (ou de endividamento) deve financiar desequilíbrios no orçamento das Previdências mencionadas e no orçamento geral da Seguridade Social.

Se o financiamento da Seguridade Social (Previdência, assistência e saúde) depende de receitas de contribuições sociais e de impostos, isso não significa que as receitas 3 políticas de Seguridade Social (saúde, assistência social e Previdência) sejam iguais ou plenamente intercambiáveis. Na realidade, a área da Previdência Social é a única regida pela diretriz do equilíbrio financeiro e atuarial. É muito oportuna, portanto, a advertência do TCU de que "tratar receitas e despesas das três áreas conjuntamente, apenas pela ótica da Seguridade Social, pode trazer limitações à análise." ${ }^{28}$ Como bem reconhece o Relatório da Auditoria, ${ }^{29}$ a política previdenciária é a única que tem receitas exclusivas (a receita das contribuições previdenciárias ou contribuições para fins previdenciários). São receitas que não podem ser utilizadas para outros fins. ${ }^{30} \mathrm{E}$ a proibição se aplica não apenas às políticas públicas fora do quadro da Seguridade Social, aplica-se também às políticas de saúde e de assistência social.

Nota-se, de imediato, que do ponto de vista econômico seria mais racional ter um só regime de Previdência Social para todos, "brasileiros em geral" e "brasileiros servidores públicos", com regras especiais para casos especiais. Toda a arrecadação obtida com receita de contribuições previdenciárias

\footnotetext{
28 TCU (2017a, p. 11, §67).

29 Idem, p. 13, § 78.

30 Assim, a receita da contribuição social devida por empregadores e calculada sobre a folha de pagamentos de pessoas jurídicas (chamada de Contribuição Previdenciária Patronal do setor privado) e a receita obtida com a Contribuição Previdenciária devida por empregados e calculada sobre sua própria folha mensal de pagamentos (CRFB, Art. 195, I, a; e Art. 195, II) essas duas modalidades de contribuições previdenciárias têm regras especiais: a receita deve ser aplicada exclusivamente na política de Previdência do RGPS. Sobre a proibição de aplicação de receitas arrecadadas com a Contribuição Previdenciária incidente sobre folha de salários em outras finalidades, ver também a Nota Técnica n. 5/ASTEC/SOF/MP, do Ministério do Planejamento, Orçamento e Gestão, item 2.1.1.
} 
e demais contribuições sociais seria usada para um só fundo de Previdência, e para os demais fundos de saúde e assistência social. A diferença deveria ser coberta com controle de evasão, de sonegação, de corrupção, de cobrança de dívidas, de redução de desperdícios. A elevação de impostos ou tributação diferenciada para pessoas jurídicas de setores que empregam pouco trabalho formal e que tem alta lucratividade, deveria ser a penúltima medida numa lista aberta de opções. $\bigcirc$ endividamento público, só em caso de emergência e de impossibilidade de realização das medidas anteriores.

Assim como está, a sociedade "em geral" paga duas vezes (para o RGPS e para o RPPS) e paga ainda mais para cobrir déficits do RGPS, do RPPS e dos EPU. É um modelo complexo demais para uma jovem república democrática, de uma sociedade injusta pelo seu crônico grau de desigualdade social, economicamente pouco competitiva e que precisa de transparência e eficiência na gestão das coisas públicas.

\section{Cristal trincado: receitas que dependem de emprego formal, controle da sonegação e cobrança de dívidas}

Ainda que a primeira impressão aponte para um sistema complexo de tributos dragando receitas para a Seguridade Social, quando se analisam os dados da Auditoria do TCU sobre receitas, ${ }^{31}$ chega-se rapidamente à conclusão de que poucos tributos seguram as contas do sistema. Sem considerar a incidência da DRU, ${ }^{32}$ duas fontes de receitas, apenas, respondem por $78 \%$ do que é arrecadado pela Seguridade Social: contribuições previdenciárias e COFINS.

Em primeiro lugar, merece destaque o papel desempenhado pelas Contribuições Previdenciárias. Ainda mais porque essa receita é rigidamente protegida pelo direito constitucional brasileiro. Como já mencionado antes, os recursos arrecadados com esse tributo destinam-se, exclusivamente, ao pagamento de aposentadorias e pensões previstas no plano de cobertura

31 As receitas pertencentes à Seguridade Social são regidas pela Nota Técnica n. 05/ASTEC/SOF/MP, de 03.11.2003, com atualizações dadas pela Nota Técnica n. 05/DEAFI/SOF/MP, de 27/01/2016, que define a natureza de cada uma.

32 A Desvinculação de Receitas da União (DRU) é um procedimento autorizado por Emenda à Constituição desde 01.03.1994, no contexto das medidas iniciais de implementação do Plano Real durante o governo Itamar Franco, em que o Ministro da Fazenda era Fernando Henrique Cardoso. A desvinculação criada sempre tem sido temporária. No entanto, ao final do período temporário o Congresso Nacional aprova nova Emenda à Constituição e, assim, o temporário converte-se em algo permanente. A redação original está no Art. 72, IV dos ADCT (ECR, n.1, 1994) que autorizou, pela primeira vez, que $20 \%$ das receitas obtidas com as Contribuições Sociais pudessem ser desviadas do Orçamento da Seguridade Social para compor o Fundo Social de Emergência. A redação mais recente está no Art. 76 dos ADCT (EC n. 93/2016), que estabelece o seguinte: São desvinculados de órgão, fundo ou despesa, até 31 de dezembro de 2023, 30\% (trinta por cento) da arrecadação da União relativa às contribuições sociais, sem prejuizo do pagamento das despesas do Regime Geral da Previdência Social, às contribuições de intervenção no domínio econômico e às taxas, já instituídas ou que vierem a ser criadas até a referida data. A proposta que deu origem a esta nova DRU foi encaminhada em 01. jul. 2015, pelo Ministério do Planejamento e pelo Ministério da Fazenda (EMI n. 88/2015, MP MF), sob a Presidência de Dilma Rousseff, antes da crise do impeachment, que iniciou em 02.dez. 2015, quando a Denúncia foi aceita pela Câmara dos Deputados. A exposição de motivos da PEC tem apenas 6 parágrafos e ocupa apenas 1 folha e meia. É rápida e superficial, indicando singelamente que a prorrogação da DRU é necessária porque a estrutura fiscal e orçamentária possui elevado volume de despesas obrigatórias, o que tende a extinguir a discricionariedade alocativa do governo. Quer dizer, do ponto de vista republicano, essa exposição de motivos não passa num teste mínimo de accountability. Apenas diz que o governo tem poucos recursos e que precisa, urgentemente, de mais dinheiro. Nada além. 
previdenciária (do RGPS administrado pelo INSS, num caso; e do RPPS, noutro). ${ }^{33}$ Somadas as modalidades patronal e de empregados, as contribuições previdenciárias respondem por 45\% de todas receitas da Seguridade Social. ${ }^{34}$ Logo em seguida vem a Cofins, que incide sobre a receita bruta das pessoas jurídicas. Esse tributo responde por $28 \%$ do que se arrecada para a Seguridade Social. ${ }^{35}$

Como o conceito de Seguridade Social envolve também os regimes de Previdência de servidores públicos, então o restante (22\%) advém de contribuições previdenciárias pagas por servidores públicos ${ }^{36}$ aos fundos de Previdência desses servidores e que não se confundem com os recursos administrados pelo INSS (4,2\%), e também de pagamentos feitos por pessoas jurídicas ao ${\mathrm{PIS} / \mathrm{PASEP}^{37}(4,41 \%) \text { e à CSLL }}^{38}$ (9,29\%). Uma parte inferior a 0,5\% advém de receitas dos concursos e prognósticos. ${ }^{39}$

Olhando assim é fácil ver que a folha de salários é a principal base de cálculo da política tributária que financia a Seguridade Social no Brasil. É a tributação da folha de salários que fornece a fatia de $51 \%$ das receitas ${ }^{40}$ para esse sistema operar. Em segundo plano, o sistema brasileiro tributa o lucro (CSLL) e a receita bruta (Cofins e PIS) de pessoas jurídicas. A receita obtida com esses tributos correspondente a $41,6 \%$ do total. ${ }^{41}$

Esses números revelam algo muito importante: o financiamento da Seguridade Social não recai exclusivamente na conta dos segurados da Previdência. Essa conclusão é importante para lidar com o frequente argumento de que se os brasileiros envelhecerem no ritmo esperado pelas projeções da PEC 287, e assim deixarem de contribuir (porque muitos se aposentam e a população em idade ativa decresce) então desaparecerá o financiamento da Seguridade Social. É claro, agora, que a folha de salários é a base tributária mais relevante para o financiamento desse sistema. Todavia, a ordem jurídica brasileira tem meios para, se necessário, equilibrar as contas da seguridade com mudanças na política tributária. Se aumentar a produtividade das empresas e também o trabalho informal, o volume de inativos e o desemprego, a lucratividade de setores tradicionais ou de novos setores intensivos em tecnologia também se elevará. Nessa hipótese a manutenção do atual volume de financiamento da Seguridade Social pode ser viabilizada com uma política tributária mais concentrada na CSLL, COFINS e PIS, e menos nas contribuições incidentes sobre folha de salários.

\footnotetext{
33 É bom não confundir: servidores públicos, empregados e empregadores que contratam empregados pelo regime da CLT, esses 3 contribuintes pagam contribuições previdenciárias mensalmente. Todavia, o destino da arrecadação não é o mesmo. A receita dos pagamentos efetuados por servidores públicos é destinada ao Fundo de Previdência dos Servidores Públicos. Já a receita arrecadada com as contribuições previdenciárias pagas por empregados e empregadores que contratam pelo regime da CLT vai para o Fundo do Regime Geral de Previdência Social, administrado pelo INSS.

34 Em 2016, o valor aproximado foi de R 340 bi. Ver Relatório TCU (2017a, Quadro 4, \$ 99, p. 15).

35 Em 2016, o valor aproximado foi de R 200 bi. Idem

36 Em 2016, o valor aproximado foi de R 30 bi.

37 Em 2016, o valor aproximado foi de R 67 bi. Idem

38 Em 2016, o valor aproximado foi de R\$ 32 bi. Idem

39 Em 2016, o valor aproximado foi pouco mais de R\$ 2 bi.

40 Em 2016, o valor arrecadado com a contribuição previdenciária destinada ao RGPS e ao RPPS, respondeu por 51,15\% do total das receitas da Seguridade Social, e um valor próximo de R \$370,2 bi.

41 Em 2016, o valor arrecadado com esses 3 tributos foi de R $\$ 301,7$ bi.
} 
Esse cenário revela que o atual modelo de financiamento da Seguridade Social é muito sensível às oscilações no mercado formal de trabalho, no lucro e no faturamento das empresas. Por esse ângulo, o modelo atual das contas da Seguridade Social tem 4 vilões muito claros: (1) a recessão econômica, (2) políticas trabalhistas que afetem negativamente o volume de emprego formal, (3) medidas de incentivo econômico ancoradas na desvinculação de receitas de contribuição previdenciária e de COFINS (seja por meio de imunidade, isenção ou políticas de desoneração), (4) e a negligência no controle de sonegação, de recuperação de créditos e de corrupção.

Enquanto a longevidade tem impacto no desequilíbrio atuarial nas contas da Seguridade Social (isto é, impacto relevante a partir de 2031 e, efetivamente, a partir de 2040), o cenário recessivo e escolhas políticas restritivas de receitas têm reflexos imediatos, pois afetam no curto prazo o equilíbrio financeiro da Seguridade Social, e agravam o cenário atuarial de longo prazo.

\section{Despesas de seguridade social: quais são?}

Muito embora os principais riscos sejam os apontados acima, é preciso dizer que tal conclusão só faz algum sentido se as despesas atuais forem pertinentes, ou seja, se cada pagamento ou transferência de recursos da Seguridade Social, de fato, realizar os objetivos da segurança social. Para avaliar isso, os registros contábeis precisam ser compreensíveis e precisos. Do contrário, como saber se, de fato, a frustração de receitas decorre de cenário econômico, de políticas que desviam receitas da Seguridade Social ou de gastos indevidos?

Quanto a isso, impressiona ler a crítica do Relatório do TCU. O modo adotado pelo governo para registrar as despesas da Seguridade Social inviabiliza uma conclusão precisa sobre a pertinência das despesas. A equipe técnica do Tribunal de Contas da União foi extremamente crítica quanto isso. $\mathrm{Na}$ avaliação do TCU, os dados disponíveis na contabilidade pública são obscuros e é muito difícil e complexo apresentar informações à sociedade brasileira com base nesse tipo de registros. O motivo da dura crítica é que faltam "critérios formais e transparentes sobre a composição das principais áreas de despesas do orçamento da seguridade". ${ }^{42} \mathrm{Na}$ realidade, faltam "critérios mínimos de alocação das despesas no orçamento da seguridade e nas suas respectivas áreas (Previdência, saúde e assistência social)" ${ }^{43}$

Bom exemplo dos efeitos dessas inconsistências nos dados da Previdência é a variedade de respostas para uma pergunta simples: qual é a despesa do RGPS? Consideramos o ano de 2015, que foi particularmente importante para essa discussão da crise fiscal e o papel da previdência, pois foi o primeiro ano de gestão segregada dos recursos do RGPS, isto é, o primeiro ano de plena operação do Fundo do RGPS. Esse ano também é importante porque foi o momento agudo da crise política que levou ao impeachment da Presidenta Dilma Rousseff e também foi o momento em que iniciou a

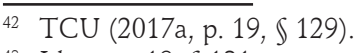

43 Idem, p. 19, \131. 
recessão econômica. Em meio a isso, surgiu com força o discurso da Reforma da Previdência. Muito embora seja difícil, ao menos com as informações disponíveis ao público até agora, estabelecer causalidades entre esses eventos, é válido o esforço de tomar as contas do RGPS desse ano de 2015 em particular para tentar responder a esta singela pergunta: qual é o volume de despesas do RGPS?

As respostas variam como segue.

No Quadro sobre Balanço Financeiro da Prestação de Contas da Presidenta da República, para o ano de 2015, do Relatório de 2015, consta (p. 327) que a despesa da Previdência Social (RGPS) foi de $\mathrm{R} \$ 328,3$ bi, ${ }^{44}$ sem qualquer detalhamento de como esse número foi composto.

No Boletim Estatístico da Previdência Social, Dez/2015, consta que a despesa do RGPS para aquele ano foi de R \$372,9 bi (INSS, 2015, p. 9). Nesse Boletim há um rigoroso detalhamento de informações que permitem ver gastos com aposentadorias, pensões e auxílios de natureza previdenciária, como também as outras despesas não previdenciárias, mas inerentes ao conceito de Seguridade Social, como são os benefícios de natureza Assistencial e também aquelas despesas com Encargos especiais Previdenciários da União.

Em Relatório emitido pelo DataPrev, ${ }^{45}$ no sítio virtual da Previdência, Resumo de Benefícios Emitidos em 2015, consta que a despesa da Previdência Social em 2015 foi de R 421,8 bi, sem qualquer detalhamento.

Já no Relatório que estamos analisando aqui da Auditoria do TCU 2017, no Anexo III, p. 107, consta que a despesa do RGPS para 2015 foi de R \$430,5 bi (e nesse caso o TCU assume que apenas usou os dados disponibilizados pela Previdência e, portanto, o dado aparece sem qualquer detalhamento).

No Balanço Financeiro do FRGPS para o ano de 2016, emitido em janeiro de 2017, consta que no ano de 2015 os dispêndios do fundo chegaram a R\$431,6 bi. ${ }^{46}$ Mas não há detalhamentos. Esse mesmo número aparece também no já mencionado Relatório de Prestação de Contas da Presidenta da República Dilma Rousseff, para o ano de 2015, publicado em Abr/2016. Consta que a despesa do RGPS para o ano de 2015 foi de R \$431,9 bi (p. 122). Esse número persiste noutro relatório oficial, pode ser encontrado na p. 338 das informações adicionais da Prestação de Contas do atual Presidente Michel Temer, ${ }^{47}$ publicado em abril de 2017 (p. 338). Nesses dois últimos relatórios há algum detalhamento de informações. Não chega ao bom nível de esclarecimentos da despesa específica de cada um dos benefícios pagos pelo RGPS, como acontece no caso do BEPS/Dez/2015, mas são bem melhores do que os anteriores e permitem ver, ao menos, como cálculo foi elaborado,

44 Disponível em: www.cgu.gov.br/assuntos/auditoria-e-fiscalizacao/avaliacao-da-gestao-dos-administradores/prestacao-de-contas-do-presidente-da-republica/exercicios-anteriores/2015. Acesso em: 17 dez. 2017.

45 Disponível em: www3.dataprev.gov.br/scripts10/dardoweb.cgi. Acesso em: 17 dez. 2017.

46 Disponível em: portal.inss.gov.br/wp-content/uploads/2017/05/Balan\%C3\%A7o-Financeiro_FRGPS_2016.pdf. Acesso em: 19 dez. 2017.

47 Disponível em: http://www.cgu.gov.br/assuntos/auditoria-e-fiscalizacao/avaliacao-da-gestao-dos-administradores/ prestacao-de-contas-do-presidente-da-republica/arquivos/2017/pcpr-2016-informacoes-adicionais.pdf. Acesso em: 18 dez. 2017. 
ou seja, a partir dos gastos com Aposentadoria do RGPS - Área Urbana, Pensões do RGPS - Área Urbana, Aposentadoria do RGPS - Área Rural, Outros Benefícios do RGPS - Área Urbana e Pensões do RGPS - Área Rural.

Os números podem se elevar ainda mais se outros documentos forem consultados. Vejamos. No mesmo Relatório da auditoria do TCU 2017, porém no Anexo VII, p. 112, consta que a despesa do RGPS para 2015 foi de R \$46,09 bi, novamente sem qualquer detalhamento. Esse número coincide com o que se pode observar no Anuário Estatístico da Previdência Social (ano 2015), ${ }^{48}$ no Capítulo 40, item 40.3, sobre Fluxo de Caixa Mensal consolidado do FRGPS. Consta que para o ano de 2015 a despesa com benefícios previdenciários foi de $\mathrm{R} \$ 436,0$ bi (p. 741). Contudo, não há detalhamento que permita ver a especificação desses dados. Consta apenas a seguinte discriminação: benefícios INSS: R \$ 424,7 bi; sentenças judiciais TRF: R \$ 8,6 bi; sentenças judiciais INSS R \$ 962 milhões; Compensação previdenciária: R \$ 1,7 bi; benefícios devolvidos: R \$2,0 bi.

Por outro lado, no Relatório de Gestão da Secretaria de Políticas de Previdência Social, exercício de 2015, publicado em de março de 2016, consta (sem qualquer detalhamento) que a despesa com benefícios previdenciários foi de $\mathrm{R} \$ 454,0 \mathrm{bi}^{49}$ (p. 33). Já no resultado do regime geral de Previdência Social - RGPS, ano 2016, p. 18, divulgado em Jan/2017 pela Secretaria da Previdência, consta que a despesa com benefícios para o ano de 2015 foi de $\mathrm{R} \$ 483,8$ bilhões. ${ }^{50}$

Diante desse lamentável quadro de inconsistência de informações sobre a natureza das despesas, a Auditoria do TCU conseguiu chegar a um valor apenas aproximado para a proporção dos gastos efetuados pela área da Previdência em relação ao todo dos gastos da Seguridade Social. Considerando o RGPS, o RPPS e o regime dos militares, o TCU estima que tais gastos previdenciários corresponderam, em média, a 67\% dos gastos da Seguridade Socia ${ }^{51}$ no período que vai de 2007 a 2016. Já em relação aos gastos com saúde e assistência social, a Auditoria expressou grande inconformidade com o fato de que sequer poder segregar os valores exatos pertencentes a cada área. "Essa dificuldade em separar esses valores é decorrente, como já afirmado, da falta de formalização e transparência dos conceitos e critérios utilizados pelo governo para alocação das despesas." ${ }^{2}$

\section{A seguridade social financiando o caixa do governo e a competitividade empresarial}

Muito relacionado ao ponto anterior é o esclarecimento sobre a destinação de receitas das contribuições sociais. Como dito antes, esses recursos devem ser usados exclusivamente para financiar

\footnotetext{
48 Disponível em: www.previdencia.gov.br/dados-abertos/dados-abertos-previdencia-social. Acesso em: 15 dez. 2017.

49 Disponível em: www.previdencia.gov.br/wp-content/uploads/2016/10/atuaprocont15spps.pdf. Acesso em: 18 dez. 17.

50 Disponível em: www.previdencia.gov.br/wp-content/uploads/2017/01/Resultado_RGPS_Ano_2016.pdf. Acesso em: 15 dez. 2017.

51 Idem, p. 21, \$ 146.

52 Idem, p. 20, §136.
} 
saúde, assistência e Previdência; e no caso das contribuições estritamente previdenciárias, devem ser aplicados exclusivamente no financiamento das necessidades previdenciárias. Contudo, há desvios.

Agora, nem todos os desvios foram estabelecidos por leis ou depois da Assembleia Nacional Constituinte. Entender a redação original do $\$ 1^{\circ}$ do Art. 239 da CRFB, é um bom começo. $\bigcirc$ texto indica que a própria Assembleia Constituinte desviou 40\% dos recursos arrecadados com uma das contribuições sociais (o PIS/Pasep) para financiar programas de desenvolvimento econômico por meio do Banco de Desenvolvimento Econômico e Social (BNDES). A medida é inteligente e não contraria a filosofia da segurança social da CRFB. Se a proteção da renda dos trabalhadores pode ser feita mediante transferências passivas do Estado para cada trabalhador, também pode ser feita assim, mediante indução de atividade econômica geradora de emprego e de renda salarial. Precisa apenas ser efetiva. O caso das receitas do PIS/Pasep é exatamente esse e precisa de acompanhamento constante. Todavia, mesmo assim é preciso reconhecer que se trata de um caso originário de desvio de receitas do orçamento da Seguridade Social para outra política pública: no caso, de desenvolvimento econômico e de geração de emprego.

Depois, o Congresso Nacional, por sucessivas Emendas à Constituição, a partir de 1994, autorizou outra modalidade de desvio de receitas: a DRU, ou seja, a Desvinculação de Receitas da União - que atualmente desvia 30\% do total arrecadado com algumas contribuições sociais. ${ }^{53}$

O Relatório ${ }^{54}$ explica também que o Congresso Nacional autorizou, via legislação ordinária, alocar parte das receitas de concursos de prognósticos para as áreas de educação e cultura ${ }^{55}$ e de segurança. ${ }^{56}$

Outro importante fator de desvios de receitas pode ser notado no Relatório do TCU. Ao analisar as transferências feitas pelo Tesouro Nacional ${ }^{57}$ para o Orçamento da Seguridade Social, os dados da Auditoria explicitam que parte desses recursos correspondem a devoluções para cobrir as diferenças criadas pela política de desoneração $0^{58}$ das contribuições sociais. $O$ impacto dessa política não é nada singelo. A soma de todas as desonerações no período de 2012-2016 representou

53 Ver EC 93/2016.

54 TCU (2017a, p. 13, \$ 83).

55 Fundo Nacional da Cultura, Lei 8.313/1991, art. 5, VIII e Fundo de Investimento do Estudante Superior - Lei 10.260/2001, art. $2^{\circ}$, II.

56 Fundo Penitenciário Nacional, Lei Complementar 79/1994, art. 2º, VIII.

57 Só em 2015-2016 o valor aproximado dos desvios causados pela política de desoneração foi de R\$39,5 bi. Ver TCU (2017a, Quadro 20, p. 59, \$349).

58 A Lei 12.546, de 14/12/2011 instituiu desonerações para as seguintes contribuições sociais: a) contribuição previdenciária incidente sobre a folha de pagamento para o setor de tecnologia da informação, hoteleiro, construção civil, construção de obras de infraestrutura, transporte rodoviário coletivo de passageiros, transporte ferroviário e metroviário de passageiros (Art. $7^{\circ}$ ); b) PIS e COFINS na aquisição no mercado interno ou de importação de máquinas e equipamentos destinados à produção de bens e prestação de serviços; c) CSLL, nos dispêndios efetivados em projeto de pesquisa científica e tecnológica e de inovação tecnológica executado por Instituição Científica e Tecnológica (ICT). A política geral de desoneração com base na Medida Provisória 540, depois convertida na Lei 12.546/2011 reduziu, em alguns casos, a base de cálculo, noutros a alíquota desses tributos. No todo foram 16 setores e 56 atividades beneficiadas: Administração, Agricultura, Assistência Social, Ciência e Tecnologia, Comércio e Serviço Comunicações, Cultura, Defesa Nacional, Desporto e Lazer, Educação, Energia, Habitação Indústria, Saúde, Trabalho e Transporte. O TCU (2017a, p. 18, \$ 116) apurou que no período de 2012 a 2016, só com a contribuição previdenciária patronal deixaram de ser arrecadados aproximadamente R 77 bi. 
R\$ 646,7 bi. E dos valores desonerados, 86,3\% foi aplicado fora ${ }^{59}$ da área da Seguridade Social. Em Nota Técnica recente (06.11.2017) o Ministério da Fazenda explicou que atualmente (dez/2017) tramita no CN uma proposta de revogação dessa política. Em 2015, o Congresso Nacional aprovou, com modificações, a proposta do Executivo, que se transformou na Lei $n^{\circ} 13.161 / 2015$. "Essa Lei estabeleceu alíquotas variando entre 1\% e 4,5\%, e deu às empresas a opção de escolher entre a tributação sobre a folha ou sobre o faturamento." ${ }^{60}$ As empresas optaram por não mais pagar contribuições previdenciárias sobre a folha de pagamentos e paga-las pela menor alíquota e, ainda, incidente sobre faturamento. A estimativa do governo é que em 2017 mais de 40.000 contribuintes da Seguridade Social continuam optando por pagar contribuição social com as alíquotas menores ou com a base de cálculo sobre o faturamento.

\section{0 mérito das escolhas políticas que envolvem orçamento da seguridade social}

Visto isso, podemos avançar para mais um componente extremamente importante desse Relatório da Auditoria do TCU, e que diz respeito ao desequilíbrio entre despesas e receitas do Orçamento da Seguridade Social. ${ }^{61}$ Está muito claro que nos 10 anos examinados pelo TCU (2007 a 2016) os gastos globais da Seguridade Social evoluíram acima das receitas e também acima da inflação. Isso indica, obviamente, a existência de desequilíbrios financeiros e, portanto, de déficit no orçamento da Seguridade Social. Contudo, há uma particularidade nesse déficit. Nem todas as fontes de despesas da Seguridade Social evoluíram de modo a ter seus gastos globais acima das receitas e também acima do índice de inflação. Nesse período, as despesas com a área da saúde e com a assistência social ${ }^{62}$ permaneceram estáveis em relação à evolução desses indicadores. Os gastos crescentes são de natureza previdenciária, ${ }^{63}$ e dentre os gastos previdenciários, 2/3 correspondem ao orçamento do RGPS e 1/3 à somatória de RPPS e EPU. Assim, não pode haver dúvidas quanto a um fato simples: há um desequilíbrio financeiro no Orçamento da Seguridade Social provocado, particularmente, pelas contas da Previdência.

De fato, não há como negar a força persuasiva da interpretação do TCU em relação a esses balanços e demonstrativos financeiros. É digno de nota, porém, que o TCU tomou um cuidado muito especial ao formular suas conclusões sobre os resultados encontrados. Em três momentos politicamente muito sensíveis, o Relatório realça - usando até letras em negrito - que não faz

59 TCU (2017a, p. 61, §359).

60 Nota Técnica 041, 06.11.2017, do Ministério da Fazenda, disponível em: https://fazenda.gov.br/centrais-de-conteudos/ notas-tecnicas/2017/nota-reoneracao.pdf/view. Acesso em: 14 dez. 2017.

${ }^{61}$ Idem, p. 20, \$141 e dados do Anexo II e III, p. 105-108.

62 Idem, p. 22, Gráfico III.

63 Considerando o RGPS, o RPPS e o EPU dos militares, as receitas previdenciárias cresceram $43 \%$ e as despesas, $47 \%$ nesses 10 anos. E a necessidade de financiamento aumentou 54\%. Em 2016 isso representou R $\$ 227$ bilhões. Desse total, 65,9\% se refere ao RGPS, 18,9\% ao RPPS de servidores civis da União e 15,01\% ao sistema de proteção social dos militares, p. 98 , \624. 
parte do escopo do [seu] trabalho emitir opinião acerca do mérito das informações encontradas, ${ }^{64}$ nem do mérito das destinações definidas na legislação para a DRU, ${ }^{65}$ nem dos resultados das políticas de desoneração da folha de salários de mais de 40.000 empresas. ${ }^{66}$

Sendo um órgão técnico de fiscalização da legalidade das ações de execução orçamentária, realmente, não cabe ao TCU opinar sobre as escolhas políticas que criaram as regras atualmente vigentes e que produziram esses resultados. ${ }^{67}$ Se as regras da desvinculação de receitas da DRU ou as da desoneração tributária existem ao lado de outras que aumentaram as despesas, e se todas são válidas, cabe ao Tribunal de Contas apenas explicar o tipo de impacto gerado por tais regras, e não julgar as escolhas políticas aprovadas pela arena democrática. $\bigcirc$ mais importante para um Relatório Técnico como esse que estamos analisando é afirmar o que acaba de ser afirmado: o desequilíbrio, nessas circunstâncias, e de acordo com as regras vigentes, realmente existe.

Por outro lado, o papel que a análise acadêmica pode - e deve - desempenhar nos debates públicos é bem outro. Se o trabalho técnico do TCU deve se concentrar nas incoerências e irregularidades e também na avaliação de impactos das escolhas democráticas, não se deve esperar que a mesma restrição à liberdade de expressão se aplique ao discurso acadêmico-científico. Neste caso, a crítica é o proposito deste paper, e a base de dados da auditoria do TCU, é o material básico que nos guia.

Com base nos próprios dados oficiais oferecidos pelo TCU é importante indagar e procurar saber se o déficit persistiria caso os recursos da DRU e da política de desoneração fossem corretamente devolvidos para a Seguridade Social. Afinal, se nessa conclusão o TCU opera com os dados atuais e confiáveis, o tamanho do desequilíbrio causado pela elevação das despesas previdenciárias pode ser diferente, com e sem os recursos das desvinculações e desonerações. É o que precisamos compreender.

\section{A dança dos números}

Como era de esperar, o volume do desequilíbrio muda drasticamente se a avaliação das contas da Seguridade Social considerar (ou não) as receitas desviadas ${ }^{68}$ pela DRU e as receitas renunciadas pela política de desonerações da folha de salários.

\footnotetext{
64 Ver $\int 84$, p. 14, sobre a destinação das receitas da Seguridade Social para outros fins.

65 Ver $\$ 620$, p. 98 , sobre os efeitos da DRU.

${ }_{66}$ Ver $\$ 643$, p. 101, sobre a política das desonerações tributárias.

67 Idem, p. 14, § 84.

68 Ver Anexo II, p. 105-106, item DRU DAS RECEITAS DA SEGURIDADE. Nos anos 2007 a 2009, a DRU desviou R\$ 39 bi; em 2010 foram R\$ 46,3 bi; em 2011 o valor chegou a R\$ 50,4 bi; em 2012 foi de R\$ 54,8 bi; em 2013: R\$ 60,1 bi; em 2014: R \$ 59,8 bi; em 2015: R\$ 60,6 bi e em 2016: R\$ 91, 9 bi.
} 
As contribuições previdenciárias ${ }^{69}$ do RGPS e do RPPS são espécies de contribuições sociais. ${ }^{70}$ Com a criação da DRU em 1994, 1/5 dessas receitas (20\%) estiveram sujeitas a desvinculação. ${ }^{71}$ A exceção aconteceu muito recentemente, em 2016, ${ }^{72}$ quando a atual EC 93/2016, pela primeira vez, autorizou elevar o percentual de desvinculação para 30\%, mas "sem prejuízo do pagamento das despesas do Regime Geral da Previdência Social”. Desse modo, proibiu o que já estava proibido: não é permitido desviar receitas das contribuições previdenciárias pagas pelos servidores públicos. ${ }^{73}$

O Relatório da Auditoria do TCU é animador, pois revela que não estão sendo desviados recursos das Contribuições Previdenciárias para outras finalidades. No atual modelo de DRU, "mais de $90 \%$ das desvinculações realizadas são originárias de três contribuições sociais: Contribuição Social para o Financiamento da Seguridade Social (Cofins), Contribuição Social sobre o Lucro Líquido (CSLL) e Contribuição para o PIS/Pasep."74

Muito embora o Art. 167, XI da Constituição da República proíba a utilização das receitas de Contribuições Previdenciárias do RGPS para a realização de outras despesas, como muitas vezes dito aqui, esse tema ainda não é consensual na esfera do Poder Executivo. Inicialmente, note que foi preciso reescrever o óbvio na EC 93 "sem prejuízo do pagamento das despesas do Regime Geral da Previdência Social." Depois, veja o desentendimento ainda existente no interior do Poder Executivo, entre a Secretaria de Orçamento Federal (SOF), a Procuradoria da Fazenda Nacional (PFN) e o Ministério do Planejamento (MP) sobre se os recursos dessas Contribuições Previdenciárias. A SOF até emitiu Nota Técnica interpretando que a CRFB veda tal desvinculação, seja para as contribuições do RGPS, seja para as do RPPS. A PFN, por sua vez, ainda não está convencida. Por isso recorreu à Consultoria Jurídica do Ministério do Planejamento e, mesmo vencida, recorreu à Controladoria Geral da União (que não expressou opinião até o fechamento do Relatório da Auditoria do TCU).

\footnotetext{
69 As receitas desta contribuição social estão estritamente vinculadas ao pagamento de benefícios do regime geral da Previdência Social. Por causa da redação dada pelo Art. 167, XI - é vedada ... a utilização dos recursos provenientes das contribuições sociais de que trata o art. 195, I, a, e II, para a realização de despesas distintas do pagamento de benefícios do regime geral de Previdência Social de que trata o art. 201 - esta contribuição social passou a ser chamada de contribuição previdenciária. A legislação brasileira não prevê uma lista específica com os tipos de contribuições sociais. A Lei $8.212 / 91$ prevê apenas que haverá cobrança de contribuições sociais sobre diferentes bases de cálculo. Essa denominação contribuição previdenciária tornou-se usual - e passou a ser adotada pela doutrina, jurisprudência e até pela legislação, porque $100 \%$ do que é arrecadado com base na folha de salários (sejam contribuições sociais pagas por empregadores, sejam as pagas por empregados) deve ser - e é - destinado ao Fundo Previdenciário do Regime Geral da Previdência Social. É bom lembrar que os servidores públicos também pagam uma modalidade de contribuição previdenciária. No entanto, a receita arrecadada migra para o fundo de previdência dos servidores públicos, e não para o FPRGPS.

70 Ver Lei 8.212/91, Art. 11. No âmbito federal, o orçamento da Seguridade Social é composto das seguintes receitas: I - receitas da União; II - receitas das contribuições sociais; III - receitas de outras fontes. Parágrafo único. Constituem contribuições sociais: a) as das empresas, incidentes sobre a remuneração paga ou creditada aos segurados a seu serviço; b) as dos empregadores domésticos; c) as dos trabalhadores, incidentes sobre o seu salário-de-contribuição; d) as das empresas, incidentes sobre faturamento e lucro; e) as incidentes sobre a receita de concursos de prognósticos.

71 De 1994 até o final de 1999, a base de incidência da DRU eram todas as contribuições arrecadadas pela União, sem ressalvas. Depois veio a EC 27/2000, que fixou a incidência da DRU apenas sobre as Contribuições Sociais, deixando de fora as contribuições de intervenção no domínio econômico e a contribuição para o salário-educação. Outra mudança ocorreu em 2003, com a EC 42. Desde então a DRU passou a incidir também sobre as contribuições de intervenção no domínio econômico.

72 TCU (2017a, p. 54, \$317).

73 Idem, p. 54, §315-316.

74 Idem, p. 53, § 312.
} 
Ainda que o TCU também tenha se oposto à interpretação da PFN e entenda que não cabe desvincular esses recursos, ${ }^{75}$ até julho de 2017 não havia uma decisão oficial sobre o tema na esfera do Poder Executivo.

Essa divergência impressiona, mas não deveria existir: primeiro porque a DRU nunca desviou nenhum recurso das contribuições previdenciárias. A Auditoria do TCU é categórica nesse ponto. $^{76}$ Depois porque esse tema é muito bem regulado pelo texto constitucional desde a EC 20/1998. Não existe autorização para desvincular as receitas das Contribuições Previdenciárias.

É certo que a política de desoneração da folha de salários afetou as receitas das Contribuições Previdenciárias, na medida em que o governo federal entendeu que poderia "renunciar tais receitas". Mas esse é um caso sutilmente diferente da DRU. Trata-se de uma política baseada na renúncia prévia de receitas. O governo decidiu arrecadar menos na medida em que autorizou mais de 40.000 empresas a pagar a Contribuição Previdenciária de modo bem diferente, com redução de alíquota e cálculo baseado em faturamento (não em folha de salários). Esse favor para as empresas deve ser compensado posteriormente, com devoluções para o orçamento da Seguridade Social - muito embora com registros contábeis irregulares! ${ }^{77}$

Um ponto importante é o seguinte: o cenário ideal para desviar receitas do Orçamento da Seguridade Social para outras finalidades existe? Sim, existe. Se o valor que restar para a Seguridade Social cobrir suas necessidades de pagamento, não haveria problema em desviar - temporariamente - parte de seus recursos próprios para outras finalidades de interesse públicos. Do contrário, isto é, se o desvio temporário de receitas apenas fragiliza o sistema de segurança social, seria preciso reduzir despesas da seguridade social (com o alto risco de prejudicar seriamente os brasileiros em situação de maior vulnerabilidade econômica e de saúde) ou mobilizar recursos de outras fontes (e.g., controlar a sonegação, a evasão, o desperdício, cobrar dividas atrasadas, etc). Outra solução seria elevar a alíquota de contribuições sociais de setores que empregam pouco, que tem alta lucratividade e baixa tributação, como é o caso do setor do agronegócio. Outra, ainda, seria elevar alíquota de impostos de setores que pagam pouco, mas esta última solução seria um movimento circular pouco eficiente: retirar receitas obtidas com contribuições e depois devolvê-las com receitas obtidas com impostos.

O problema é que nesses casos meramente exemplificativos, o Orçamento da Seguridade Social deixaria de realizar sua finalidade constitucional para se converter numa espécie de financiador de "capital de giro" do Tesouro Nacional.

\footnotetext{
75 Idem, p. 55, \324.

76 Dada a relevância do tema, vale a pena citar, na íntegra, a conclusão do TCU: Após levantamento dos valores das receitas previdenciárias dos últimos dez anos (2007 a 2016), constatou-se que, à exceção das receitas de contribuição para custeio das pensões militares e de multas e juros sobre as contribuições patronal e do servidor do regime próprio, nenhuma outra receita de contribuição previdenciária sofreu incidência da DRU. Em decorrência disso, o encargo da DRU, suportado pela previdência, tornou-se inexistente, no caso do RGPS, e minimo, para o RPPS (TCU, 2017a, p. 55, \$325).

77 Os valores devolvidos "são contabilizados como receitas do RGPS, para fins de apuração do seu resultado financeiro, mas não são contabilizados como receitas da Seguridade Social”. Ver Relatório do TCU (2017a, p. 18, \118).
} 
Os dados coletados pela Auditoria do TCU deixam ver mais coisas. Vamos observar ${ }^{78}$ o volume de transferências feitas pelo Tesouro Nacional à Seguridade Social. Em geral essas transferências são qualificadas como socorro do Tesouro nacional para "cobrir o rombo da Previdência". Mas é preciso mais serenidade antes de concluir assim. Por exemplo, nos últimos 10 anos o Tesouro transferiu para a Seguridade Social o valor de $\mathrm{R} \$ 873,12$ bi. $^{79}$ E só nos últimos 5 anos transferiu R\$ 672,6 bi. ${ }^{80}$ Contudo, nos mesmos 10 anos que cobrem 2007 a 2016, o total das desvinculações que saíram da Seguridade Social para o Tesouro Nacional alcançou R \$1,46 tri. ${ }^{81}$ É bom lembrar que só a DRU respeitou as receitas exclusivas das Contribuições Previdenciárias, mas não a política de desoneração. A DRU, sozinha, desviou de outras contribuições sociais o valor de R\$ 541 bi. ${ }^{82}$ Agora veja a concentração de desvinculações apenas nos últimos 5 anos que envolvem 2012 a 2016. Nesse curto período, o governo utilizou em outras áreas nada menos que $\mathrm{R} \$ 974,1 \mathrm{bi}^{83}$ do orçamento da Seguridade Social.

Caso esses valores transferidos pelo Tesouro Nacional para o orçamento da Seguridade Social nos últimos 5 anos sejam tomados sem contextualização, os valores parecem indicar um rombo monumental nas contas da Seguridade Social. Tem-se a impressão de que recursos do Orçamento Fiscal precisam socorrer (com impostos e endividamento) um sistema colossalmente deficitário de Seguridade Social.

Todavia, o Relatório da Auditoria do TCU permite compreender que uma parte expressiva desses aportes feitos pelo Tesouro Nacional, seja na última década, ou então no último quinquênio, correspondem a devoluções. Se nesse período de 5 anos o governo aplicou nada menos que R $\$ 974,1$ $\mathrm{bi}^{84}$ da Seguridade Social em outras finalidades, não é exagero concluir que não fez nenhum socorro ao devolver R \$ 672,685 bi. Ao contrário: cumpriu (incompletamente) sua obrigação prevista na ordem jurídica de devolver recursos.

Pelas regras vigentes o governo pode desvincular recursos da Seguridade Social para aplicálas noutras finalidades. Todavia, a natureza jurídica dessa operação assemelha-se a um empréstimo, não a uma doação. A desvinculação ou desoneração de receitas de Contribuições Sociais (excetuado o caso das Contribuições previdenciárias) não pode desfalcar o Orçamento da Seguridade Social. Assim, os recursos desviados pela DRU e os recursos não arrecadados por causa da política que mudou a base de cálculo e da alíquota da Contribuição Previdenciária patronal para alguns setores da economia, esses recursos precisam ser devolvidos à Seguridade Social.

\footnotetext{
78 Ver p. 22 e 23, gráfico 4.

79 TCU (2017a, p. 22, \148).

80 TCU (2017a, p. 22, \148, Gráfico 4).

81 O valor corresponde à soma de R $\$ 925,0$ bi (desonerações, p. 58, $\$ 348$, Quadro 19) com o valor de R \$541,9 bi (DRU das receitas da Seguridade Social, p. 106, Anexo II)

82 TCU (2017a, p. 55, §330).

83 O valor corresponde à soma de R \$ 646,7 bi (desonerações, p. 58, \$348) com o valor de R\$327,3 bi (DRU das receitas da Seguridade Social, p. 106, Anexo II).

84 Idem.

85 TCU (2017a, p. 22, \148, Gráfico 4).
} 
Na realidade entre 2012 a 2016, nada menos que 46,3\% de todas as transferências feitas pelo governo para a Seguridade Social, correspondem a devoluções. São recursos que só saíram do Orçamento da Seguridade Social porque a sociedade brasileira precisou socorrer o Governo e o Orçamento Fiscal da União. Isso indica que os efeitos da crise fiscal, concentrada na expansão da dívida mobiliária do governo federal, foi amenizada com recursos do orçamento da Seguridade Social. O déficit no RGPS — que existe — não é, nem de longe, o principal responsável pela explosão da crise fiscal nos últimos 3 anos, nem muito menos é o principal responsável pela elevação da dívida bruta do governo geral. ${ }^{86}$

A Tabela 1, abaixo, foi composta a partir de dados fornecidos pelo Relatório do TCU. Ajuda a ver a composição do déficit acumulado no período de 2012 a 2016.

Tabela 1 - OSS - Orçamento da Seguridade Social | 2012-2016 - Valores em R\$ bi

\begin{tabular}{|c|c|c|c|c|c|c|}
\hline \multicolumn{7}{|c|}{ OSS - ORÇAMENTO DA SEGURIDADE SOCIAL | 2012-2016 - Valores em R\$ bi } \\
\hline & 2012 & 2013 & 2014 & 2015 & 2016 & TOTAL \\
\hline RECEITAS DO OSS & 596.9 & 657.9 & 686.9 & 706.4 & 724.1 & 3.372 .3 \\
\hline Desvio causado pela DRU (Emenda Constitucional) & 54.8 & 60.1 & 59.8 & 60.6 & 91.9 & 327.3 \\
\hline $\begin{array}{l}\text { Desvio causado pela política de Desoneração da } \\
\text { Contrib. Previd. Patronal (Lei 12.618/2012) }\end{array}$ & 90.2 & 119.4 & 140.2 & 153.0 & 143.7 & 646.7 \\
\hline RECEITA DO OSS (COM DRU) & 542.1 & 597.8 & 627.0 & 645.7 & 632.2 & 3.045 .0 \\
\hline RECEITA DO OSS (COM DRU e Desoneração) & 451.9 & 478.3 & 486.7 & 492.7 & 488.4 & 2.398 .2 \\
\hline DESPESAS OSS & 600.9 & 669.2 & 740.6 & 796.5 & 874.7 & 3.682 .1 \\
\hline $\begin{array}{c}\text { DESEQUILÍBRIO } 1 \\
\text { (sem DRU e Desoneração) }\end{array}$ & -4.01 & -11.2 & -53.7 & -90.1 & -150.5 & -309.7 \\
\hline $\begin{array}{l}\text { DESEQUILÍBRIO } 2 \\
\text { (com DRU) }\end{array}$ & -58.8 & -71.3 & -113.67 & -150.7 & -242.4 & -637.1 \\
\hline $\begin{array}{c}\text { DESEQUILÍBRIO } 3 \\
\text { (com DRU e Desoneração) }\end{array}$ & -149.0 & -190.8 & -253.9 & -303.8 & -386.2 & -1.283 .8 \\
\hline Diferença de desequilíbrios (1-3) & -145.0 & -179.5 & -200.1 & -213.6 & -235.7 & -974.1 \\
\hline \multicolumn{7}{|c|}{$\begin{array}{l}\text { Fonte: organizada por Carlos Luiz Strapazzon a partir dos dados disponibilizados pelo Tribunal de Contas da União no Rela- } \\
\text { tório de Auditoria TC 001.040/2017-0. Rel: Ministro José Múcio Monteiro, de 21.06.2017. Levantamento. Sistema brasileiro } \\
\text { de Previdência. Apuração de informações acerca do déficit e do financiamento do sistema previdenciário. Para ver os dados } \\
\text { sobre as Receitas do OSS, o volume do desvio causado pela DRU e o total da receita antes da incidência da DRU, consultar } \\
\text { Anexo II, p. 106. Para ver os dados sobre valores desonerados pela Lei 12.618/2012, consultar Quadro 19, p. } 58 \text {. }\end{array}$} \\
\hline
\end{tabular}

Se o Congresso Nacional e o Governo consideram que devolver o que foi tomado emprestado da Seguridade Social é, como tem de ser, uma devolução, então é claro que o Tesouro

\footnotetext{
86 Ver, quanto a isso, o diagnóstico do TCU sobre as causas da expansão da dívida bruta do Governo Geral: $A$ elevação do endividamento bruto decorreu, principalmente, da alta variação da divida mobiliária do Tesouro Nacional (em 2015 , era de $R \$ 2.640$ bilhões e, no final de 2016, foi para $R \$ 2.975,8$ bilhöes), das operações compromissadas do Bacen (em 2015, era de R\$913,3 bilhões e, no final de 2016, de $R \$ 1.047,5$ bilhões) e da divida bancária dos governos estaduais e municipais, que cresceu, respectivamente, $R \$$ 12,2 bilhões e $R \$ 4,9$ bilhões. [...] Esse expressivo endividamento nacional é fortemente pressionado pelas altas taxas de juros nominais pelas quais o Brasil remunera seus credores. Como proporção do PIB em 2016, os juros nominais do Brasil foram o terceiro maior do mundo, ficando atrás apenas do Iêmen e do Egito (FMI) (TCU, 2017b, p. 101-102).
} 
Nacional não faz um favor à Seguridade Social. Antes cumpre sua obrigação ao devolver recursos. Esse entendimento, porém, não elimina o déficit.

O Relatório do TCU não deixa dúvidas de que existe déficit ainda que o governo regularize as devoluções. $O$ déficit acumulado nos últimos 5 anos foi de R \$ 309,7 bilhões. Agora, se o Congresso Nacional e o Governo entendem que não existe obrigação jurídica de devolver integralmente os recursos desviados pela a DRU e pela política de desoneração - o que é bem possível, pois o relatório das devoluções contidas no Relatório do TCU é inconclusivo quanto a isso - e que os repasses efetuados correspondem a um socorro praticado pelo Tesouro Nacional ao orçamento da Seguridade Social, nesse caso, o déficit acumulado saltaria para R \$ 1.2 tri. A diferença do chamado "rombo da previdência" torna-se, facilmente, 4 vezes superior ao real.

Seja como for, o fato é que considerar a devolução como obrigatória e devolver $100 \%$ de tudo o que é tomado emprestado do orçamento da Seguridade Social faz toda a diferença nessa discussão.

O único modo de saber como pensa o Governo é ver como procede, ou seja, como realiza o registro contábil e como apresenta seus balanços e orçamentos. Para uma parte específica dos recursos desviados do Orçamento da Seguridade Social o TCU tem informações muito precisas. Tratam-se dos recursos mobilizados com a política de desoneração das contribuições sociais. ${ }^{87}$

Tanto o governo quanto a imprensa têm argumentado que essa política de desoneração da folha de salários se tornou um problema sério para o programa de equilíbrio fiscal implementado a partir de dezembro de $2016 .{ }^{88}$ Ao que tudo indica, ${ }^{89}$ essa política que desonerou os custos tributários de mais de 40.000 empresas, liberando-as do pagamento regular de obrigações com a Seguridade Social, não atingiu seus objetivos: elevar a competividade internacional e aumentar a contratação formal de trabalhadores. Evidentemente que isso é um problema grave. O Relatório do TCU, porém, identificou problemas desconhecidos até a publicação dos resultados da auditoria. Há erros de registro do reembolso efetuado pelo Tesouro Nacional para compensar a política de desoneração da folha de salários. Quer dizer: ainda que o Tesouro Nacional devolva parte dos recursos desviados da seguridade social (não há evidências de que devolveu 100\% do que renunciou), a devolução não é registrada corretamente. $\bigcirc$ problema é que os registros contábeis (com e sem erros) estão sendo usados nos debates públicos para decidir sobre a Reforma, particularmente, a força necessária das medidas a serem adotadas contra o RGPS. Porém, esse tipo de erro contábil sugere que o déficit do orçamento da Seguridade Social é maior do que efetivamente é.

\footnotetext{
87 Só em 2016, a política de desoneração desviou 20,3\% do total das receitas da Seguridade Social. Do total das desonerações, 84\% corresponde valores das Contribuições Previdenciárias e COFINS, 9\% do PIS/PASEP e 7\% da CSLL (TCU 2017a, p. 57, $\$ 343-344)$.

88 Refiro-me à aprovação da Emenda Constitucional n. 95/2016, que instituiu a política de "teto de gastos", no contexto do chamado Novo Regime Fiscal

89 Ver Ansiliero et al. (2008).
} 
A Auditoria do TCU aponta, apenas como exemplo, que houve erro ${ }^{90}$ na contabilização da devolução de R \$7,8 bi, decorrentes da desoneração da folha de pagamentos no período de 20122016. Se de um lado a mudança ${ }^{91}$ na base de cálculo das Contribuições Previdenciárias favoreceu setores importantes da economia, de outro, gerou a obrigação ${ }^{92}$ de o Tesouro Nacional devolver esses recursos classificados como "renúncia de receitas". ${ }^{93}$ Essa devolução é vital para não distorcer o resultado financeiro do RGPS. E no caso dessa política, o problema é ainda mais grave pois operou diretamente com a renúncia de receitas de Contribuições Previdenciárias, ou seja, justamente a única modalidade de contribuição social protegida pela Constituição com a regra que exige a destinação exclusiva de suas receitas aos fins da Previdência Social..$^{94}$

O TCU constatou que apesar de o Tesouro Nacional estar realizando as tais compensações (ao menos das receitas renunciadas desse tributo chamado "contribuição previdenciária"), os valores devolvidos "são contabilizados como receitas do RGPS, para fins de apuração do seu resultado financeiro, mas não são contabilizados como receitas da Seguridade Social." ${ }^{95}$ Essa forma de registro é muito difícil de aceitar como válida. Evidentemente distorce déficits no orçamento da Seguridade Social. A consequência é que apesar de tais compensações aumentarem as disponibilidades do Fundo Previdenciário do RGPS, e assim cumprirem o disposto pelo Art. 167, XI da CRFB, esses valores devolvidos pelo Tesouro Nacional "são indevidamente excluídos do montante das receitas que pertencem à seguridade social, o que acaba por distorcer o resultado do orçamento da seguridade social apresentado no RREO".96

O TCU explicitou seu posicionamento, de maneira inconfundível, na seguinte passagem:

A partir dos exames realizados, que incluíram a confrontação dos dados enviados com aqueles constantes do Siafi e do Tesouro Gerencial e a verificação da compatibilidade com a legislação vigente, uma distorção foi encontrada nos dados relativos ao OSS divulgados por meio do RREO, que é a não consideração das receitas relativas à compensação das desoneraçöes da folha de pagamento pelo Tesouro. Assim, considera-se que os valores constantes do referido documento estão apenas parcialmente compatíveis com as receitas e despesas da seguridade apurados nesse trabalho.

$\overline{90}$ TCU (2017a, p. 18-19, \116-123).

91 Antes incidentes sobre a folha de salários e depois da política de desoneração, incidentes sobre a receita bruta e ainda com alíquotas menores que $20 \%$.

92 Ver Art. 9, IV, da Lei 12.546/2011, onde se lê: A União compensará o Fundo do Regime Geral de Previdência Social ... no valor correspondente à estimativa de renúncia previdenciária decorrente da desoneração, de forma a não afetar a apuração do resultado financeiro do Regime Geral de Previdência Social (RGPS).

93 Cfe. Nota Técnica 041, 06.11.2017, do Ministério da Fazenda, p. 1: "O valor total de contribuição previdenciária pago pela maioria das empresas incluídas no programa diminuiu, o que significou, para as empresas, redução de custos. Para a Previdência houve uma redução de receita, contabilizada como renúncia fiscal. As perdas incorridas pela Previdência são ressarcidas pelo Tesouro Nacional à Previdência".

94 Desde 1998, o Art. 167, XI da CRFB prevê a seguinte proibição: É vedada a utilização dos recursos provenientes das contribuições sociais de que trata o art. 195, I, a, e II, para a realização de despesas distintas do pagamento de benefícios do regime geral de Previdencia Social de que trata o art. 201.

95 Ver Tabela I do Demonstrativo das Receitas e Despesas da Seguridade que consta do Relatório Resumido da Execução Orçamentária (RREO) de 2016 (TCU, 2017a, p. 18, \$ 118).

96 RREO - Relatório Resumido da Execução Orçamentária, Ver tb. p. 19, \123. É esse documento exigido pela Lei de Responsabilidade fiscal que vem sendo adotado pelo Governo, inclusive pelo TCU, nos relatórios de contas da União, nas justificativas da Lei Orçamentária Anual e nas propostas de Reforma da Previdência. 
Isso quer dizer duas coisas: primeiro, que o governo devolveu menos do que aproveitou, ${ }^{97}$ segundo, que pela contabilidade oficial tudo se passa como se o Tesouro Nacional estivesse fazendo transferências para a Seguridade Social.

O Relatório não explica como foram registradas as devoluções da DRU para os desvios com as demais Contribuições Sociais (excetuadas as Contribuições Previdenciárias pois, como dito antes, o TCU esclarece que a DRU desviou recursos da Seguridade Social. No entanto, tais recursos não saíram das receitas exclusivas da Previdência Social. A DRU, assim, não desviou recursos arrecadados com a Contribuição Previdenciária incidente sobre folha de salários. Mas seu impacto é real no significado do déficit do RGPS, dado que a DRU incide sobre as contribuições sociais para financiamento da seguridade (Cofins), sobre o lucro líquido (CSLL) e sobre o PIS/Pasep. É fora de dúvida que a DRU amplia o significado do déficit e também que os governos cumpriram a proibição estabelecida no Art. 167, XI, da Constituição da República: não desviaram — com a DRU — receitas exclusivas da Previdência.

\section{0 peso do regime dos servidores públicos na conta do deficit}

Neste ponto, é crucial notar que tanto o sistema especial de Previdência (convencionalmente chamado de Regime Próprio - RPPS) para servidores públicos, quanto o sistema geral para todos os demais brasileiros (dito Regime Geral - RGPS) têm déficit, mesmo que 100\% das receitas desviadas do Orçamento da Seguridade Social seja devolvido. Importante lembrar também que o déficit da Previdência é a soma dos déficits dos 10 regimes existentes. ${ }^{98}$

Por outro lado, o Relatório oferece dados extremamente relevantes para entender o que representa cada segurado desses regimes. "Os valores nominais de receita e despesa per capita do RPPS da União são 484\% maiores do que do RGPS." $" 99$

Quer dizer, em termos comparados, o custo individual de cada servidor público para o total do déficit, é muitas vezes superior ao custo de manutenção da proteção previdenciária para um brasileiro que não trabalha na administração pública federal. Essa uma distorção baseada numa tradição de considerar a previdência de servidores públicos como se fosse continuidade do trabalho. Aposentadoria considerada como folha de salário. Tratar os servidores públicos assim traz ótimos dividendos políticos para os governantes eleitos, mas tal irresponsabilidade gerou um custo extremamente alto para toda a sociedade. Agora que o problema está posto, e muito claramente, há uma tendência de "fulanizar" o déficit e de apontar os servidores públicos como "vilões". Não é essa a

\footnotetext{
97 É preciso lembrar que nesse período de 2012 a 2016 o volume de recursos desviados por causa da política de desoneração da folha de salários alcançou a cifra de R\$ 646,7 bi, ver Quadro 19, \$348, p. 58 do Relatório do TCU.

98 Obviamente, isso é fruto da complacência dos brasileiros com a desigualdade, pois não há razões políticas tão fortes que justifiquem tantos regimes e tanta diferença entre eles.

99 TCU (2017a, p. 29, \194).
} 
tese deste texto. O Brasil tolerou essa desigualdade imoral. Agora precisamos corrigi-la com o menor custo para os grupos mais vulneráveis.

\section{Por que o déficit da previdência aumentou tanto a partir de 2011?}

Por um lado, pode-se dizer que as alterações de 2015 que mudaram a aplicação do fator previdenciário, criando a regra 85/95, facilitou a aposentadoria por tempo de contribuição de trabalhadores urbanos e, seguramente, isso teve repercussões sobre o volume do déficit. $\bigcirc$ Relatório do TCU não é categórico quanto a isso, mas admite essa possibilidade.

Por outro lado, esse período recente coincide com o momento agudo da recessão econômica. Essa sim é uma afirmação categórica da Auditoria do TCU. Concluiu que "o substancial crescimento das despesas do RGPS em relação ao PIB pode ser explicado, em parte, pelo forte período recessivo observado no Brasil nos exercícios de 2015 e 2016." Nesses dois anos a economia do país recuou 7,2\% e o desemprego avançou. Dado que a base das contribuições para a Seguridade Social são a folha de salários (de empregados e empregadores), e a receita bruta das empresas, "o RGPS é mais sensível às flutuações da economia, que afetam diretamente suas receitas e podem provocar aumento na demanda de alguns benefícios previdenciários." 100 ○ Relatório reforça essa interpretação para estabelecer que "o expressivo aumento do déficit do RGPS no período 2014-2016, de R\$ 67 bilhões para R $\$ 149$ bilhões, pode ser atribuído, em grande medida, à crise econômica do período." ${ }^{101}$ Essa mesma análise e conclusões o TCU repetiu por ocasião do Parecer Prévio que emitiu para a aprovação das contas do governo federal no ano de 2016.102

Assim, não pode restar qualquer dúvida quanto ao fato muito simples: as despesas do RGPS aumentaram expressivamente nos últimos 3 anos por causa da queda da arrecadação tributária motivada pela recessão. Esse aumento fora do normal para as despesas do RGPS se deve muito mais à queda nas receitas do que a um aumento autônomo das despesas.

\section{Transparência, dados inconsistentes, projeções irrealistas, metodologias inadequadas}

As projeções feitas pelo Governo Federal têm sido determinantes para as discussões sobre o desenho final que deve assumir a reforma da Previdência. Essas projeções têm sido publicadas em forma de gráficos e tabelas disponíveis em estudos técnicos que, por sua vez, têm sido incorporados a Propostas de Emenda à Constituição e a projetos de Lei. O Relatório da Auditoria do TCU coloca especial ênfase na baixa qualidade técnica desses prognósticos. Como era de esperar, esse tema abre

\footnotetext{
100 TCU (2017a, p. 40, \$247).

$101 \mathrm{TCU}(2017 \mathrm{a}, \mathrm{p} .43, \mathbb{\$} 254)$.

102 TCU (2017b, p. 94).
} 
outra frente de críticas ao modo como a discussão está sendo conduzida. Cito aqui algumas dessas passagens críticas elaboradas pelo TCU para que se tenha uma avaliação inicial.

[...] somente os dados obtidos do Executivo foram considerados satisfatórios... para todos os outros Poderes, os dados fornecidos se mostraram insatisfatórios, chegando a haver diferenças de $211 \%$ entre o montante total pago aos funcionários ativos do Legislativo apresentado no Siafi e o total calculado a partir dos dados enviados pelos órgãos do Poder Legislativo. (TCU, 2017a, p. 48, \$281).

Chamam a atenção as estimativas relativas ao PIB. As mesmas taxas de crescimento do PIB foram utilizadas nos PLDO de 2016 e 2017 para o período de 2020 a 2060, mas esses índices sofreram alterações substanciais na avaliação do PLDO 2018. Enquanto no PLDO 2016 essa taxa variou de 3,70\% em 2022 para 1,07\% em 2060, no PLDO 2018 a variação foi de $2,81 \%$ para $0,74 \%$. No período de 2020 a 2060, a taxa média de crescimento utilizada no PLDO 2016 foi de 2,1\% ao ano, enquanto no PLDO 2018 essa taxa foi de 1,61\% ano. [...]. Comparando essas taxas projetadas com a média de crescimento do PIB brasileiro no período de 1996 a 2016 (2,38\% ao ano), percebe-se que a média de crescimento da economia projetada para o longo prazo é inferior à que foi aferida nos últimos vinte anos... [em síntese] as projeções atuariais do PLDO 2018 apenas citam que as variáveis (entre elas, a taxa de crescimento real do PIB) foram elaboradas a partir de dados da Grade de Parâmetros SPE/MF de 13/3/2017. Não há explicações sobre as diferenças para as projeções anteriores ou a pouca aderência da taxa projetada de crescimento do PIB aos valores históricos apurados. (TCU, 2017a, p. 46-47, \$ 273-276).

A regra de reajuste do salário mínimo atualmente vigente é válida desde 2008 (Lei 11.708/2009) e está prevista para durar até 2019 (Lei 13.152/2015). No entanto, está sendo utilizada na projeção atuarial para anos posteriores a 2019. Diante da atual conjuntura econômica, das restrições orçamentárias e da EC 95, que limitou o teto dos gastos público por 20 anos, é questionável se será aprovada a manutenção da atual regra de reajuste do salário mínimo para todo o período projetado, até 2060. (TCU, 2017a, p. 47, \$278).

Esse tema das estimativas abre a discussão para a qualidade técnica do cálculo atuarial sobre o equilíbrio futuro das contas do FRGPS. É que a Lei de Responsabilidade Fiscal (LRF) determinou, em 2000, a criação do FRGPS - do Fundo do Regime Geral de Previdência Social. Criar esse fundo seria recomendável para assegurar transparência na movimentação de recursos destinados ao pagamento dos benefícios do RGPS. Além disso, aprimoraria a gestão do orçamento da União, pois seria possível evitar confusões com a origem e destino das receitas tributárias da União e também permitiria avaliar corretamente o equilíbrio financeiro e atuarial do RGPS.

Surpreendentemente, a criação do Fundo só ocorreu 14 anos depois, em 2014. Consequentemente, até então o nível de transparência necessários para a apuração de resultados, variação patrimonial, compensações para outros regimes, ficou comprometida. O TCU avalia que problema dos dados com os quais a Secretaria da Previdência vem operando está muito suscetível à ocorrência de erros que "podem produzir significativos impactos no orçamento da seguridade". ${ }^{103}$

$\overline{103}$ Idem, p. 77, \461. 
Se, por um lado, a criação do Fundo deveria ser comemorada por ser, afinal, um passo crucial para a transparência na gestão dos recursos da Previdência, por outro, a segregação dos valores dessa política social deveria gerar um consistente modelo de avaliação do equilíbrio atuarial do sistema. Sem avaliação de equilíbrio atuarial, como seria possível avançar a discussão dos rumos de uma reforma?

Mas com base em que, então, a PEC 287, a Secretaria da Previdência e os Projetos de Leis Orçamentárias fazem projeções sobre ativos e passivos do RGPS para 2040 e 2060? Qual é o grau de confiabilidade dos dados futuros para justificar as propostas de "correções" no modelo atual do RGPS?

Apesar de todo o esforço, que merece respeito e consideração pela elevada qualidade técnica dos dirigentes e da equipe técnica da Secretaria da Previdência do Governo Federal, estimativas e modelagens de longo prazo para a o caso da Previdência Social são um fenômeno inteiramente novo no debate público do Brasil. A própria equipe técnica que elaborou a projeção atuarial do RGPS reconhece isso. ${ }^{104}$

Tudo indica que as estimativas foram feitas com base metodologia pouco conhecida e cuja consistência foi escassamente discutida no Brasil. Tanto é assim que a Previdência Social está pedindo ajuda ao Banco Mundial para fazer os prognósticos sobre equilíbrio ou desequilíbrios futuros. Além disso, a modelagem apresentada no PLDO 2018 ressalva-se da natureza provisória e suscetível de variações já no curto prazo. Como afirma o texto do PLDO 2018,

[o]s resultados [das estimativas] são fortemente influenciados pelas hipóteses relativas à dinâmica da demografia, do mercado de trabalho, do funcionamento do sistema previdenciário (hipóteses comportamentais dos indivíduos) e da própria economia como um todo (PIB, produtividade, inflação). Logo, eventuais revisões nas projeções desses parâmetros ou a observação de resultados no curto prazo diferentes dos projetados implicam, necessariamente, a revisão das projeções de longo prazo. ${ }^{105}$

É certo que esse fato não veio a público com o destaque merecido. Não obstante, é com base nessa metodologia pouco debatida e pouco conhecida - até mesmo da Secretaria da Previdência - que a Reforma da Previdência está sendo proposta nos termos da PEC 287 e da PLDO 2018.

Quanto aos detalhes técnicos das estimativas relativas ao equilíbrio atuarial, há duas passagens bem significativas, e constantes do Anexo IV.6, ${ }^{106}$ do PLDO 2018, que merecem atenção. A primeira é a seguinte:

É fundamental o entendimento de que o arcabouço metodológico desse modelo [de projeção atuarial para o RGPS] segue padrões internacionais tais como os modelos amplamente utilizados pelo Banco Mundial (Modelo Prost $\square$ Pension

\footnotetext{
104 PLDO 2018, Anexo IV.6, p. 48.

${ }^{105}$ Idem, p. 48-49.

106 Disponível em: www.planejamento.gov.br/assuntos/orcamento-1/orcamentos-anuais/2018/pldo-2018/anexo-iv-6-projecoes-atuariais-do-rgps.pdf/view. Acesso em: 19 dez. 2017.
} 
Reform Options Simulation Tool kit) e pela Organização Internacional do Trabalho (ILOPension Model). (BRASIL, 2017, p. 27).

A segunda passagem é a seguinte:

[o] modelo de projeções fiscais de receitas e despesas previdenciárias e assistenciais funciona de acordo com a Figura 1 abaixo. Inicialmente, parte-se da projeção das quantidades de benefícios (estoques), a qual se dá por meio de estimativas da dinâmica do fluxo de entradas (concessões) e saídas (cessações) de benefícios do sistema, as quais, por sua vez, refletem a transição demográfica em curso no país. Em seguida, é projetada a evolução dos preços fundamentais para o comportamento da despesa previdenciária, ou seja, dos rendimentos médios de diversos subconjuntos populacionais bem como dos valores e dos reajustes dos benefícios. Por fim, são projetados os valores, referentes ao cômputo das despesas e receitas, bem como das massas salariais de subconjuntos populacionais e crescimento do PIB. Por fim, nota-se que o modelo é determinístico, ou seja, a partir da fixação de um conjunto de variáveis, o modelo determina de maneira única seus resultados (BRASIL, 2017, p. 29). ${ }^{107}$

Em síntese, o Governo estimou a quantidade de benefícios futuros a partir do atual fluxo de concessões até 2015, e projetaram as quantidades futuras a partir da estimativa do IBGE para a longevidade crescente e natalidade decrescente da clientela do RGPS e da população economicamente ocupada e contribuinte, com segmentação para a clientela rural e urbana, e ainda com diferenças para homens e mulheres. Modelaram estimativas diferentes para o custo futuro de aposentadorias, auxílios, salário-maternidade, pensões. Estimaram também que os benefícios futuros precisarão ser reajustados a partir do impacto da inflação futura na renda média da clientela do FRGPS. Cruzaram esses dados com as projeções de PIB.

Então, é um modelo assentado no fluxo atual de concessões ampliado segundo a variação projetada de longevidade, mais a correção de valores medida pela estimativa de inflação no poder aquisitivo médio da clientela do RGPS. Tudo isso, combinado com as estimativas de crescimento do PIB.

Muito embora o RGPS não deva ser confundido com a política assistencial, nem muito menos o significa de previdência com o de assistência social, é muito significativo que as estimativas do PLDO 2018 tenham incluído no custo futuro da Previdência, todas as despesas com benefícios assistenciais. ${ }^{108} \mathrm{E}$ com todos os detalhes da modelagem matemática.

\footnotetext{
107 Esse modelo, no entanto, não é puro, nem gera respostas definitivas. São estimativas que requerem constante atualização de informações. O documento informa que "o procedimento metodológico ... implementado na atualização do modelo é a calibragem, por meio da qual são realizados testes comparativos entre as projeções do modelo e os dados realizados de benefícios, e, a partir disso, são realizados ajustes finos em alguns parâmetros do modelo com o intuito de reduzir os erros de previsão. Ademais, as projeções são atualizadas à medida em que são disponibilizadas novas informações mais recentes sobre benefícios, novas projeções de parâmetros macroeconômicos e alterações da legislação previdenciária em vigor." (BRASIL, 2017, p. 41).

108 PLDO 2018, Anexo IV.6, p. 36. Cito: Os 4 (quatro) tipos de Benefícios Assistenciais (Loas Idoso, Loas Deficiente, RMV Idoso e $R M V$ Deficiente) são modelados seguindo o método do fluxo exposto na equação (28). 14 Ademais, o Fator de Ajuste da Mortalidade (Ecii, tt sscLL) e a Probabilidade de Concessão de Benefício ( $\rho \rho i i, t t$ sscLL) são estimados de acordo com as equações (29) a (31). Acrescenta-se que a Probabilidade de Concessão no RMV é nula ( $\rho \rho i i, t t$ sSc RRR RR=0), pois o benefício está em extinção (sem novas concessões).
} 
Por outro lado, na estimativa de valor futuro dos benefícios previdenciários, não consideraram a regra constitucional de que esses benefícios devem ter, no mínimo, o valor do salário mínimo. A igualdade de valores entre benefícios previdenciários, benefícios assistenciais e o salário mínimo foi tratada como exceção, e não como regra nessas projeções. ${ }^{109}$ A medida padrão das correções foi a estimativa de inflação.

Tomando um comentário do TCU relativo à consistência metodológica dos cálculos atuariais adotados para o RPPS, o Relatório afirma que o PLDO 2018 elaborado pelo Governo Federal considerou, para ser mais cauteloso, que todos os servidores públicos que já cumpriram os requisitos para se aposentar tomariam essa decisão em 2017. O prognóstico, assim, é de que o fluxo financeiro, no curto prazo, fique mais apertado.

Mas - pergunta-se o Relatório do TCU - no caso da Previdência Social, será, realmente, mais cauteloso fazer esse tipo de suposição conservadora? Esse modelo de prognóstico foi criticado pelo TCU por duas razões: primeiro porque não é realista (e todo prognóstico que afeta direitos fundamentais e interesses públicos deve ser); depois porque tal suposição faz com que o cálculo opere com menos descontos, o que projeta grande diminuição na contribuição e grande aumento nos pagamentos. Portanto, eleva o volume de déficit do RPPS. ${ }^{110}$ Além disso, o método de apuração de sustentabilidade do RPPS foi explicitamente considerado inadequado a essa finalidade por não seguir padrões internacionais. ${ }^{111}$ Para o TCU, "o déficit apontado na avaliação atuarial do PLDO 2018 não permite concluir sobre sustentabilidade financeira ou equilíbrio previdenciário"112 do RPPS.

É certo que esse comentário crítico do TCU ao RPPS não poderia, sem mediações, ser aplicado diretamente à consistência científica das projeções realizadas para o caso do RGPS. Entretanto, a esse respeito, chega a ser espantosa a conclusão da Coordenadoria-Geral de Estatística, Demografia e Atuária da Previdência Social, expressa em Carta-Oficio ${ }^{113}$ emitida à Presidência do INSS em 17.01.2017. Numa palavra: em total contradição com as razoes expostas no Anexo IV.6 do PLDO 2018, a Secretaria da Previdência admite que não tem os meios técnicos para fazer avaliação de equilíbrio atuarial do RGPS!

Vale a pena ler uma parte da Carta mencionada:

3. Conforme já discutido anteriormente, tendo inclusive sido objeto de Grupo de Trabalho constituído pela Portaria Interministerial CC/MF/MPS ñ 218, o conceito de Balanço atuarial não se aplica a regimes de Previdencia abertos que utilizam o sistema de repartição simples, como é o caso aplicado no Brasil ao $R G P S$, pela complexidade em se apurar os ativos atuariais.

\footnotetext{
109 Idem, p. 38.

${ }^{110}$ Idem, p. 48, § 285.

${ }^{111}$ Idem, p. 48, § 291.

112 TCU (2017a, p. 49, §291-292).

113 Disponível em: www.previdencia.gov.br/wp-content/uploads/2017/01/Notas-Explicativas_FRGPS_2016_Vers\%C3\%A3o-Final.pdf. Acesso em: 10 dez. 2017.
} 
4. A partir da apuração desse ativo, que em um regime com as características do RGPS que não possuem formação de capital e assim é formado exclusivamente pelas contribuições futuras, seria possivel chegar ao déficit atuarial do regime.

5. Conforme previsto na página 12 do Relatório Final do referido Grupo de Trabalho, encontra-se em andamento em parceria com o Banco Interamericano de DesenvolvimentoBID, estudo para estimar as contribuições futuras para trazê-las a valor presente e assim construir um balanço atuarial.

6. Em substituição, esta Secretaria de Políticas de Previdência Social vem emitindo estimativas sobre as receitas e despesas do RGPS para horizonte de tempo até o ano de 2060, às quais são incorporadas projeções populacionais e tábuas de mortalidade, 0 que fornece elementos atuariais à estimativa e que vêm sendo utilizadas na composição dos Projetos de Lei Orçamentária Anual e nos Relatório Resumido de Execução Orçamentária. ${ }^{114}$

A falta de evidenciação da situação atuarial do RGPS é um grave problema de justificativa da atual agenda de reformas, quer seja do RPPS, cuja metodologia foi criticada pelo TCU, quer seja do RGPS, cuja metodologia de apuração do equilíbrio atuarial - como reconhecido em 2017 pela Coordenadoria-Geral de Estatística, Demografia e Atuária da Previdência Social — simplesmente não existe.

Mas não é só. A gestão do RGPS também padece de outros problemas que só agravam a compreensão do estado atual das coisas e também a formação de prognósticos de tão longo prazo. $\bigcirc$ TCU também aponta que os demonstrativos patrimoniais do atual FRGPS subavaliam os ativos do Fundo! Simplesmente, não há registros dos "créditos tributários a receber e a dívida ativa tributária", e não são divulgados os "critérios de ajuste para perdas que representa 96\% da dívida ativa não tributária do Fundo". Além disso, o TCU ${ }^{115}$ notou que faltam Notas Explicativas às demonstrações financeiras do Fundo e também das demonstrações financeiras individuais do Fundo.

Consideremos - só por um instante - que a Procuradoria da Fazenda Nacional publicou em seu sítio ${ }^{116}$ oficial que o estoque da dívida ${ }^{117}$ ativa previdenciária atingiu o montante de $\mathrm{R} \$$ 432,9 bi em janeiro de 2017 e que continua crescendo a um ritmo de aproximadamente 15\% ao ano. Esse elevado percentual de créditos da seguridade social não recebidos pela Receita Federal merece toda a atenção: são créditos que estão sendo discutidos na esfera administrativa e judicial e que, portanto, encontram-se com exigibilidade suspensa. Nada menos de $45 \%$ dos créditos de Contribuições Previdenciárias de 2016 estavam suspensos em procedimentos administrativos, e 18\% por decisão judicial. Isso representa $\mathrm{R}$ \$122,84 bi. Em relação às demais contribuições da seguridade

\footnotetext{
114 Disponível em: previdencia.gov.br/wp-content/uploads/2017/01/Notas-Explicativas_FRGPS_2016_Vers\%C3\%A3o-Final. pdf. Acesso em: 15 dez. 2017.

115 TCU (2017a, p. 77, §462).

116 Disponível em: www.pgfn.gov.br/noticias_carrossel/pgfn-recupera-mais-de-r-22-bilhoes-em-creditos-previdenciarios?searchterm = maiores + deve. Acesso em: 10 dez. 2017.

117 Quanto ao perfil dos devedores das contribuições previdenciárias, o TCU constatou que 61\% deles são devedores com dívidas superiores a R \$ 1 milhão. O grupo dos 500 maiores devedores da Previdência (0,1\% do total dos devedores) responde por $20 \%$ da dívida em cobrança (R \$70,35 bilhões).
} 
o quadro é ainda pior: em 2016, 79\% estavam com exigibilidade suspensa em função de processos administrativos e judiciais. ${ }^{118}$

Dado o elevado estoque de dívida bruta do governo geral, dos déficits existentes e do volume impressionante de créditos a receber, é muito preocupante que a esta altura ainda falte metodologia apropriada para realizar o cálculo atuarial do RGPS. Muito embora essa falta seja, só por si, uma inconstitucionalidade e também um grave problema da gestão da Previdência Social, a Auditoria do TCU agrava ainda mais a credibilidade dos prognósticos e projeções feitos pela Secretaria da Previdência ao revelar que faltam estudos ou Auditorias especializadas até para avaliar a sonegação fiscal, particularmente, das Contribuições Previdenciárias.

Antes da extinção da Secretaria da Receita Previdenciária, por meio da Lei 11.457/2007, havia levantamentos sobre a estimativa de sonegação em relação à contribuição previdenciária. Muito embora o TCU já houvesse alertado para esse fato e também recomendado a realização periódica de tal acompanhamento (TC 022.107/2010-0), nada foi feito. Assim, em 2017 não há informações precisas, nem estimativas sobre sonegação de contribuição previdenciária. Isso não seria um problema se a inadimplência em relação a esse tributo não fosse 3 vezes superior à das demais contribuições sociais. Mas dado o elevado índice de inadimplência, é de supor que a sonegação seja algo crítico aqui. A conclusão do TCU, nesse ponto relativo ao controle da sonegação, também é grave. O Tribunal de Contas considera "a ausência de estudos sobre sonegação como uma importante fragilidade na gestão, já que o estudo do tema é fundamental para a adoção de estratégias eficazes para sua redução", particularmente em relação a contribuições previdenciárias e contribuições dos trabalhadores rurais. ${ }^{119}$

Diante desse quadro é possível cogitar que essas inconsistências apontadas pelo TCU possam explicar o volume de informações incongruentes sobre as contas da previdência, e particularmente, das contas do RGPS. O estudo desse tema requer bases técnicas muito confiáveis, pois o diagnóstico e o prognóstico errado do problema vai conduzir à adoção de medidas infrutíferas e, também injustas para os grupos sociais mais vulneráveis. ${ }^{120}$

\section{Falhas na política de atenção básica em saúde custam caro para a previdência}

O trabalho do TCU de auditar as contas da Seguridade Social e da Previdência Social tem um valor inestimável. Permite, de modo único, a ressonância da crítica acadêmica e o entendimento

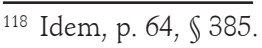

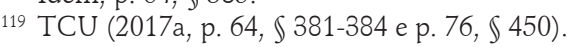

120 Sobre o efeito de prognósticos de políticas públicas em direitos fundamentais, é preciso ver o enunciado da segunda lei da ponderação de Robert Alexy, segundo a qual, quanto mais pesada for a interferência em um direito fundamental, tanto maior terá de ser a certeza das premissas nas quais essa intervenção se baseia (ALEXY, 2008, Posfácio, p. 617). Ou seja, quanto maior for o grau de restrição sofrido por um princípio constitucional, tanto maior deve ser a segurança das informações que sustentam a hipóteses, suposições e prognósticos que fundamentam a restrição.
} 
dos reais problemas que afetam a sustentabilidade do sistema brasileiro de seguridade social, particularmente, a sustentabilidade do RGPS e do RPPS.

A essa altura só falta chamar a atenção para um fato não discutido pelo Relatório do TCU e que é escassamente discutido pela literatura especializada. E diz respeito, justamente, à composição das despesas do RGPS. Esse tema é da mais alta importância, pois a PEC 287 tem um objetivo muito claro e - à primeira vista - legítimo: controlar a expansão das despesas do RGPS e do RPPS.

Nas propostas de Emenda à Constituição (original e atualizadas) que estão tramitando no Congresso Nacional é muito saliente a preocupação oficial de alterar as regras para restringir o acesso a um beneficio previdenciário com natureza de direito fundamental: a aposentadoria. ${ }^{121}$ Entre outros, esse parece ser o alvo principal da proposta de reforma pois está diretamente associado à proteção social da clientela idosa.

A leitura feita pelo Governo e pelo Congresso Nacional, ao menos até aqui, é que se não for realizada nenhuma mudança do regime de aposentadorias, a taxa de longevidade crescente associada à de natalidade decrescente deve afetar gravemente o equilíbrio atuarial do sistema de seguridade social: tudo indica que todas as contas públicas entram em colapso por volta de 2031 se nada for feito imediatamente. Esse tom de advertência está oficialmente inscrito no Anexo IV.6 do PLDO/2018 e é um bom indicativo dessa linha de discurso: Se "no ano 2016, para cada pessoa com mais de 60 anos, ter-se-á 5,3 pessoas com idade entre 16 e 59. Em 2060, esta relação deverá diminuir para 1,6.” (BRASIL, 2017, p. 23).

Esse processo [de redução da população em idade ativa] terá fortes impactos na estrutura de financiamento da Previdência Social e também na dinâmica da economia brasileira, que não contará mais com o mesmo nível atual de oferta de mão-de-obra. [N]a evolução da população em idade ativa, [é] digno de nota o ano de 2031, quando essa população atingirá seu ponto de máximo com 139 milhões de pessoas, caindo de forma monotônica a partir daí. (BRASIL, 2017, p. 20).

\footnotetext{
121 Não se pode afirmar que uma modalidade especifica de aposentadoria seja direito fundamental no Brasil (dentre as modalidades previstas em lei, seja a aposentadoria por idade, por tempo de contribuição ou por invalidez). Mas a aposentadoria, enquanto mecanismo de seguro social de renda, sem dúvida, é protegida como direito fundamental pelo texto constitucional do Brasil, no Art. $7^{\circ}$, XXIV. O fato de ser um direito constitucional assim, fundamental, torna-o um direito muito especial, porque muito protegido pelo direito brasileiro. A primeira vista, não pode ser revogado. E qualquer mudança em seu regime jurídico, requer extremado cuidado. O texto constitucional, no Art. 201, elenca uma ampla lista de situações fáticas - notadamente no inciso I - que podem ser cobertas, nos termos de Lei, por essa modalidade de direito fundamental. Essa especificação de "aposentadorias" já é feita pela Lei 8213/1991, Art. 18, a-d; Art. 42, Art. 48 e Art. 54. É certo que o texto constitucional sugere a existência de uma aposentadoria por idade na medida em que estabelece critérios de idade para que seja possível aposentar-se: Art. 201, $\$ 7^{\circ}$, II. Do mesmo modo sugere uma modalidade de aposentadoria por tempo de contribuição, uma vez que estabelece critérios de tempo de contribuição para que seja possível aposentar-se: Art. $201, \$ 7^{\circ}$. I. Todavia, é bom reforçar, o texto constitucional não explicita uma modalidade especifica de aposentadoria como direito fundamental. Explicita, sim, critérios de aposentadoria especial, de idade e de tempo de contribuição. No Brasil, portanto, existe o direito fundamental amplo de aposentadoria para trabalhadores, como direito aberto a especificações e a restrições legais. Contudo, toda e qualquer proposta de restrição de seu âmbito de proteção amplo e de seu atual modelo de regulação requer densa justificação baseada na proteção de interesses coletivos ou direitos constitucionais. Noutras palavras, é um direito que pode ser modificado e restringido, como pretende a proposta de Reforma. Todavia, para que não viole a Constituição precisa justificar-se, densamente, com argumentos de direito constitucional.
} 
Não restam dúvidas que as oscilações de idade são um componente decisivo na avaliação da capacidade financeira de um sistema de seguro (como é o caso do seguro social do RGPS) de proteger a renda de uma população. Capacidade contributiva, tempo de recebimento de benefícios e valor dos benefícios são variáveis básicas e não precisamos nos estender na discussão de sua importância.

O que surpreende é ver, por outro lado, que uma das principais despesas da Previdência Social, nos últimos 5 anos, tem sido o Auxilio Doença de origem não laboral.

Os dados disponíveis nos Anuários Estatísticos da Previdência, publicados no sítio virtual da autarquia, mostram que o custo relativo do Auxílio-doença de origem não laboral responde, sozinho, por 5,2\% de todas as despesas pagas pela Previdência Social. O valor dessas despesas alcançaram, entre 2012 a 2017, R\$ 19,7 bilhões por ano. Todavia, os valores são crescentes.

Em 2012, por exemplo, o custo foi de R\$ 14,8 bi, enquanto que em 2017 foi de R\$22,3 bi, um incremento de $\mathrm{R} \$ 7,5$ bi.

Importante ver a comparação desses números com os da área da saúde. Note que o Projeto de Lei Orçamentária da União (2019) alocou R \$22,2 bi para Atenção Básica em saúde (sendo R\$ 17,9 bi para custeio, por meio de repasses de recursos para Estados, Distrito Federal e Municípios, por meio do Piso de Atenção Básica em Saúde) e outros R \$ 3,5 bi para o Programa Mais Médicos. Ou seja, a atenção básica em saúde recebe $\mathrm{R} \$ 25,8$ bi por ano, enquanto que a previdência gasta em média $\mathrm{R} \$$ 20 bi por ano. Os custos do auxílio-doença previdenciário são, portanto, muito semelhantes aos da atenção básica em saúde, o que, por si só, exigiria uma tomada de posição do governo e da sociedade brasileira sobre a política preventiva de saúde e seus impactos nos gastos da previdência.

Essa informação tem um valor importantíssimo no contexto das preocupações sobre os meios adequados de realizar uma reforma da Previdência Social. Será mesmo eficiente fazer mudanças tão concentradas no regime de aposentadorias do RGPS sem uma articulação efetiva entre a política previdenciária, a política tributária, a política de emprego e a de atenção básica em saúde?

A análise do déficit da Previdência pode ser melhor compreendida quando se analisam os Boletins Estatísticos da Previdência Social (BEPS) e os Anuários Estatísticos da Previdência Social (AEPS). Por mais que outros documentos estejam sendo adotados como oficiais, eles são incompreensíveis ao debate público.

\section{Referências}

ALEXY, Robert. Teoria dos Direitos Fundamentais. São Paulo: Malheiros, 2008.

ANSILIERO, Graziela et al. A Desoneração da Folha de Pagamentos e sua Relação com a Formalidade no Mercado de Trabalho. Brasília, DF: IPEA, jun. 2008. (Texto para Discussão n. 1.341).

BRASIL. Ministério da Economia. Planejamento, Desenvolvimento e Gestão. PLDO 2018. Anexo IV.6. Brasília, 16 maio 2017. Disponível em: http://www.planejamento.gov.br/assuntos/orcamento-1/orcamentos-anuais/2018/pldo-2018. Acesso em: 20 nov. 2018. 
INSS. Anuário Estatístico da Previdência Social, 2015.

INSS. Boletim Estatístico da Previdência Social, v. 17, n. 2, p. 7, dez. 2012.

INSS. Boletim Estatístico da Previdência Social, v. 18, n. 12, dez. 2013.

INSS. Boletim Estatístico da Previdência Social, v. 19, n. 12, dez. 2014.

INSS. Boletim Estatístico da Previdência Social, v. 20, n. 12, dez. 2015.

INSS. Boletim Estatístico da Previdência Social, v. 21, n. 12, 2016.

INSS. Boletim Estatístico da Previdência Social, v. 22, n. 10, out. 2017.

STRAPAZZON, Carlos Luiz; TRAMONTINA, Robison. Constitucional social rights without a social security philosophy. Direitos Fundamentais \& Justiça, v. 35, p. 227-251, 2016.

TCU. Relatório de levantamento do sistema brasileiro de Previdência. [Processo]: AC-1295-22/17-P; TC 001.040/2017-0. [S. l.]: TCU, 21 jun. 2017a.

TCU. Relatório e parecer prévio sobre as contas do governo da República. Relator: Ministro Bruno Dantas. Brasília, DF: TCU, 2017b. Disponível em: http://portal.tcu.gov.br/biblioteca-digital/pareceres-previos-sobre-as-contas-do-governo-da-republica-exercicio-de-2016.htm. Acesso em: 16 dez. 2017. 